\title{
Perspectives on Proterozoic surface ocean redox from iodine contents in ancient and recent carbonate
}

\author{
Dalton S. Hardisty ${ }^{\mathrm{a}, 1, *}$, Zunli Lu ${ }^{\mathrm{b}}$, Andrey Bekker ${ }^{\mathrm{a}, \mathrm{c}}$, Charles W. Diamond ${ }^{\mathrm{a}}$, Benjamin C. Gill ${ }^{\mathrm{d}}$, \\ Ganqing Jiang ${ }^{\mathrm{e}}$, Linda C. Kah ${ }^{\mathrm{f}}$, Andrew H. Knoll ${ }^{\mathrm{g}}$, Sean J. Loyd ${ }^{\mathrm{h}}$, Magdalena R. Osburn ${ }^{\mathrm{i}}$, Noah J. \\ Planavsky ${ }^{\mathrm{j}}$, Chunjiang Wang ${ }^{\mathrm{k}}$, Xiaoli Zhou ${ }^{\mathrm{b}}$, and Timothy W. Lyons ${ }^{\mathrm{a}}$
}

Key Words: Proterozoic oxygen; Shuram isotope anomaly; carbonate diagenesis; Bahamas; iodine; metazoan evolution

\begin{abstract}
The Proterozoic Eon hosted the emergence and initial recorded diversification of eukaryotes. Oxygen levels in the shallow marine settings critical to these events were lower than today's, although how much lower is debated. Here, we use concentrations of iodate (the oxidized iodine species) in shallow-marine limestones and dolostones to generate the first comprehensive record of Proterozoic near-surface marine redox conditions. The iodine proxy is sensitive to both local oxygen availability and the relative proximity to anoxic waters. To assess the validity of our approach, Neogene-Quaternary carbonates are used to demonstrate that diagenesis most often decreases and is unlikely to increase carbonate-iodine contents. Despite the potential for diagenetic loss, maximum Proterozoic carbonate iodine levels are elevated relative to those of the Archean, particularly during the Lomagundi and Shuram carbon isotope excursions of the Paleoand Neoproterozoic, respectively. For the Shuram anomaly, comparisons to Neogene-Quaternary carbonates suggest that diagenesis is not responsible for the observed iodine trends. The baseline low iodine levels in Proterozoic carbonates, relative to the Phanerozoic, are linked to a shallow oxic-anoxic interface. Oxygen concentrations in surface waters would have at least intermittently been above the threshold required to support eukaryotes. However, the diagnostically low iodine
\end{abstract}


39 data from mid-Proterozoic shallow-water carbonates, relative to those of the bracketing time

40 intervals, are consistent with a dynamic chemocline and anoxic waters that would have

41 episodically mixed upward and laterally into the shallow oceans. This redox instability may have

42 challenged early eukaryotic diversification and expansion, creating an evolutionary landscape

43 unfavorable for the emergence of animals.

\section{1. Introduction}

45 The shallow oceans of the Proterozoic Eon were the host to both photosynthetic oxygen

46 production and the sequential origin and radiations of eukaryotes and animals (Knoll, 2014;

47 Lyons et al., 2014). Nevertheless, the current conversation about the oxygenation of the

48 biosphere, the first appearances and diversification of the earliest eukaryotes and animals, and

49 their associated oxygen demands (Mills et al., 2014; Sperling et al., 2013) has often focused

50 instead on conditions in the atmosphere (Planavsky et al., 2014) and sub-photic deep-marine

51 waters (Gilleaudeau and Kah, 2015; Partin et al., 2013; Reinard et al., 2013; Sperling et al.,

52 2015). Such comparisons are indirect, since in situ oxygenic photosynthesis in the shallow photic

53 zone provides the potential for elevated shallow-ocean oxygen at micromolar $(\mu \mathrm{M})$ levels even

54 under an anoxic atmosphere (Reinhard et al., 2016). This disconnect reflects a shortage of

55 carbonate geochemical redox proxies specific to local shallow ocean conditions. The need to fill

56 this knowledge gap is particularly critical through the mid-Proterozoic (ca. 1.8 to 0.8 billion years

57 ago or $\mathrm{Ga}$ ), which precedes the evolution of the earliest metazoans (Knoll, 2014).

58 Geochemical proxies that track the mobilization of iron and manganese in mid-

59 Proterozoic soils are consistent with mid-Proterozoic $p \mathrm{O} 2$ as low as $<0.1-1 \%$ of present

60 atmospheric levels (PAL) (Cole et al., 2016; Crowe et al., 2013; Mitchell and Sheldon, 2009;

61 Planavsky et al., 2014). If these estimates are correct, the predicted nanomolar (nM) to low $\mu \mathrm{M}$

62 equilibrium-driven levels of dissolved $\mathrm{O}_{2}$ in the surface ocean are likely to have inhibited

63 eukaryote diversification (Planavsky et al., 2014; Reinhard et al., 2016). Limited carbonate

64 paleoredox proxy records (REE's, $\mathrm{Zn} / \mathrm{Fe}$ ) are generally consistent with low atmospheric $p \mathrm{O}_{2}$ 
65 through portions of the Proterozoic (Liu et al., 2016; Tang et al., 2016) and extensive records of

66 redox-sensitive metals $(\mathrm{Mo}, \mathrm{Cr}, \mathrm{U}, \mathrm{Fe})$ in basinal black shale specifically fingerprint an anoxic

67 deeper ocean dominated by a combination of ferruginous and sulfidic (euxinic) waters

68 (Gilleaudeau and Kah, 2015; Partin et al., 2013; Reinhard et al., 2013; Sperling et al., 2015).

69 Ratios of iodine-to-calcium-magnesium, or $\mathrm{I} /(\mathrm{Ca}+\mathrm{Mg})$, in shallow-marine carbonates can

70 track the presence or absence of $\mathrm{O}_{2}$ in the shallow ocean (Hardisty et al., 2014) and the position

71 of the oxic-anoxic interface in the water column relative to the site of carbonate precipitation (Lu

72 et al., 2016). The oxidized and reduced iodine species, iodate $\left(\mathrm{IO}_{3}^{-}\right)$and iodide $\left(\mathrm{I}^{-}\right)$, respectively,

73 constitute the bulk of total dissolved iodine $\left(\mathrm{IO}_{3}{ }^{-}+\mathrm{I}^{-}\right)$in seawater (Chance et al., 2014; Emerson

74 et al., 1979; Farrenkopf and Luther III, 2002; Rue et al., 1997; Wong and Brewer, 1977). In

75 marine waters, $\mathrm{IO}_{3}^{-}$and $\mathrm{I}^{-}$concentrations are inversely correlated, with nearly uniform vertical

76 profiles of total dissolved iodine outside of a slight depletion in photic waters. Concentrations of

77 total dissolved iodine in modern seawater are near 450-500 nM (Chance et al., 2014), globally

78 uniform, and have a residence time $(\sim 300 \mathrm{kyrs})$ that is orders of magnitude longer than the

79 mixing time of the ocean. Importantly, $\mathrm{IO}_{3}{ }^{-}$exists exclusively in oxic waters, with $\mathrm{IO}_{3}{ }^{-}$reduction

80 occurring in weakly oxic waters prior to the onset of iron and sulfate reduction (Fig. 1; Emerson

81 et al., 1979; Farrenkopf and Luther III, 2002; Kennedy and Elderfield, 1987a; Kennedy and

82 Elderfield, 1987b; Rue et al., 1997; Wong and Brewer, 1977). Quantitative $\mathrm{IO}_{3}^{-}$reduction is

83 observed within anoxic basins (Emerson et al., 1979; Wong and Brewer, 1977) and in reducing

84 pore waters (Kennedy and Elderfield, 1987a; Kennedy and Elderfield, 1987b). The redox

85 behavior of iodine can be traced for ancient oceans because $\mathrm{IO}_{3}{ }^{-}$is the sole iodine species that co-

86 precipitates with carbonate rocks (Lu et al., 2010). Thus, carbonate minerals formed in anoxic

87 waters - where $\mathrm{I}^{-}$is the predominant dissolved iodine species-are not expected to incorporate

88 iodine during precipitation, as demonstrated in calcite synthesis experiments (Lu et al., 2010).

89 This expectation is consistent with previous reports noting a lack of iodine in carbonate rocks

90 prior to the Great Oxidation Event (GOE) (Hardisty et al., 2014). 
Although quantitative reduction of $\mathrm{IO}_{3}{ }^{-}$occurs within hours in low-oxygen and anoxic

92 waters (Farrenkopf et al., 1997), I- oxidation can be a slower process, with rate estimates ranging

93 from weeks to years (Chance et al., 2014; Luther III et al., 1995). Due to this redox asymmetry,

94 the largest gradients in marine $\mathrm{IO}_{3}{ }^{-}$concentrations occur within the oxycline of oxygen-minimum

95 zone (OMZs) or anoxic basins (Fig. 1; Farrenkopf and Luther III, 2002; Rue et al., 1997). In this

96 weakly oxic zone, $\mathrm{IO}_{3}{ }^{-}$reduction becomes favorable but is not quantitative and together with both

97 in situ production and ex situ input of the relatively slow oxidizing $\mathrm{I}^{-}$- transported from

98 underlying anoxic waters characterized by quantitative $\mathrm{IO}_{3}^{-}$reduction-results in steep $\left[\mathrm{IO}_{3}{ }^{-}\right]$

99 gradients (Farrenkopf and Luther III, 2002; Lu et al., 2016; Rue et al., 1997; Wong and Brewer,

100 1977). Modern seawater non-zero $\left[\mathrm{IO}_{3}{ }^{-}\right]$values of $<250 \mathrm{nM}$ are almost exclusively found in such

101 settings (Fig. 1; Chance et al., 2014; Lu et al., 2016). This low range of seawater $\left[\mathrm{IO}_{3}{ }^{-}\right]$would be

102 recorded as $\mathrm{I} /(\mathrm{Ca}+\mathrm{Mg})$ ratios of $<\sim 2.6 \mu \mathrm{mol} / \mathrm{mol}$ in carbonate, as observed in both laboratory

103 calcite-precipitation experiments (Lu et al., 2010) and direct measurements of modern carbonate

104 from low oxygen settings (Glock et al., 2014; Lu et al., 2016). Analogous to the oxyclines of

105 modern OMZs and anoxic basins, ancient carbonate with non-zero $\mathrm{I} /(\mathrm{Ca}+\mathrm{Mg})$ of less than $\sim 2.6$

$106 \mu \mathrm{mol} / \mathrm{mol}$ are interpreted to reflect precipitation within waters with local $\mathrm{O}_{2}$ levels above those

107 necessary to sustain $\mathrm{IO}_{3}{ }^{-}$accumulation, but which are also characterized by or in frequent

108 exchange with waters hosting active $\mathrm{IO}_{3}{ }^{-}$reduction (Lu et al., 2016).

109 Importantly, diagenetic effects on $\mathrm{I} /(\mathrm{Ca}+\mathrm{Mg})$ ratios have not been examined in previous

110 studies. Given that diagenetic carbonate minerals form most often from anoxic pore fluids (Loyd

111 et al., 2012; McClain et al., 1992; Schrag et al., 2013) marked by $\mathrm{IO}_{3}{ }^{-}$reduction, carbonate phases

112 are expected to be particularly sensitive to diagenetic iodine loss. Carbonates of the Proterozoic

113 Eon host the largest positive and negative $\delta^{13} \mathrm{C}_{\text {carb }}$ excursions in Earth history-the

114 Paleoproterozoic Lomagundi and Ediacaran Shuram anomalies, respectively. Although differing

115 in direction, both have been interpreted as large-scale Proterozoic oxidation events bracketing the

116 overall mid-Proterozoic low oxygen atmosphere (e.g., Fike et al., 2006; Lyons et al., 2014). 
117 However, these records are at best only indirect measures of redox conditions in the surface

118 ocean, and their relationships to the broader workings of the carbon cycle as manifested in marine

119 water column signals can be lost or overprinted during diagenesis by pore fluid chemistry (Schrag

120 et al., 2013; Swart and Kennedy, 2012). If the effects of diagenesis on $\mathrm{I} /(\mathrm{Ca}+\mathrm{Mg})$ are understood,

121 examination of $\mathrm{I} /(\mathrm{Ca}+\mathrm{Mg})$ through Proterozoic carbon isotope excursions may provide a means

122 of testing whether these records represent pore fluid or water column chemistry.

123 Here we provide the most comprehensive record of Proterozoic surface ocean redox to

124 date, specifically tracking temporal marine $\mathrm{IO}_{3}{ }^{-}$availability through a compilation of $\mathrm{I} /(\mathrm{Ca}+\mathrm{Mg})$

125 ratios from mostly shallow-marine carbonate rocks (limestones and dolostones). This data set

126 includes carbonates capturing the Shuram $\delta^{13} \mathrm{C}_{\text {carb }}$ excursion. We also provide the first constraints

127 on iodine proxy response to diagenetic alteration of recent carbonates. Through comparisons of

128 dissolved iodine cycling in modern low-oxygen versus well-oxygenated marine waters,

$129 \mathrm{I} /(\mathrm{Ca}+\mathrm{Mg})$ records from pristine modern carbonates from both redox end members, and

130 diagenetic carbonates from Neogene-Quaternary settings, we suggest that oxygenation in the

131 surface ocean following the GOE was consistent with that necessary to sustain simple eukaryotic

132 life. At the same time, the low $\mathrm{I} /(\mathrm{Ca}+\mathrm{Mg})$ ratios typical of the mid-Proterozoic reflect carbonate

133 precipitation in waters with overall low and unstable oxygen levels in close spatial proximity to

134 anoxic waters. In addition, we provide evidence against diagenesis as a driver of the Shuram 135 excursion.

\section{2. Materials}

137 We measured $\mathrm{I} /(\mathrm{Ca}+\mathrm{Mg})$ ratios of carbonate rocks $(\mathrm{n}=518)$ from 20 sedimentary 138 successions spanning the late Paleoproterozoic to late Neoproterozoic (Table 1) and combined 139 these results with previously published carbonate iodine data (Glock et al., 2014; Hardisty et al., 140 2014; Loope et al., 2013; Lu et al., 2016; Lu et al., 2010; Owens et al., 2017; Zhou et al., 2015; 141 Zhou et al., 2014). Details regarding age, stratigraphy, and complementary geochemistry for the 
142 individual sections are included in the Supplementary Materials. This data set also includes new

143 results from four previously studied carbonate sections that capture the Ediacaran Shuram

144 negative $\delta^{13} \mathrm{C}_{\text {carb }}$ anomaly: the Khufai Formation of the Sultanate of Oman (Osburn et al., 2015);

145 the Doushantuo Formation of South China; the Johnnie Formation of Death Valley, USA; and the

146 Clemente Formation of northern Mexico (Loyd et al., 2013). For this and the previously

147 published Precambrian iodine data (Hardisty et al., 2014), emphasis was placed on carbonate

148 successions with independent sedimentological evidence for shallow-marine deposition and units

149 with clear indications of secondary alteration, such as veins and metamorphism above greenschist

150 grade, were avoided.

151 To evaluate the effects of diagenetic mineral transformations on $\mathrm{I} /(\mathrm{Ca}+\mathrm{Mg})$ ratios, we

152 include a series of Neogene-Quaternary case studies to provide a comprehensive view of initial

153 iodine precipitation and subsequent modification as a function of varying primary carbonate

154 mineralogy, carbonate burial history, and related diagenetic pathways - specifically, meteoric

155 diagenesis, marine burial diagenesis, and dolomitization. The case studies are outlined below

156 (along with citations to detailed previous studies of the same localities or samples), in Table 2,

157 and in the Supplemental Materials:

158 (1) Short (ca. <16 cm) bank-top cores from the modern Great Bahama Bank, or GBB

159 (Romaniello et al., 2013; Zhang et al., 2017). These samples capture initial iodine deposition

160 with primary carbonates from a range of shallow settings and primary mineralogies near

161 Little Darby and Lee Stocking islands (Table 3; Supplementary Figs. 1 and 2).

162 (2) Montastrea annularis coral heads from the Pleistocene Key Largo Limestone, South

163 Florida. This sample set includes aragonite-to-low-Mg calcite (LMC) transitions driven by

164 subaerial exposure and subsequent diagenesis in meteoric pore waters. Post-depositional

165 organic matter remineralization during aragonite-to-calcite neomorphism has resulted in

166 negative $\delta^{13} \mathrm{C}_{\text {carb }}$ values in some of the LMC samples (Gill et al., 2008). 
167 (3) The Neogene-Quaternary Clino and Unda cores, Great Bahama Bank. These cores were

168 drilled $\sim 8 \mathrm{~km}$ apart along the western edge of the Great Bahama Bank (Supplementary Fig.

169 1). The Clino core contains a negative $\delta^{13} \mathrm{C}_{\text {carb }}$ excursion in the upper portion reflecting

170 multiple periods of subaerial exposure and subsequent aragonite-to-calcite neomorphism in

171 meteoric pore fluids (still ongoing at the top of the core), along with intervals with aragonite-

172 to-calcite neomorphism occurring exclusively in marine pore fluids and minor dolomite,

173 which were all sampled in detail (Melim et al., 1995; Swart and Melim, 2000; Swart and

174 Kennedy, 2012). The Unda and Clino cores have similar depositional histories; however, for

175 the purposes of this study, we did not sample the Unda core in the same stratigraphic detail as

176 the Clino core. For the Unda core, we specifically sampled two intervals of extensive

177 dolomite that formed in exchange with marine pore fluids (Swart and Melim, 2000).

178 (4) Dolomite concretions of the Miocene Monterey Formation, California. These samples

179 represent dolomite derived mainly from alkalinity production and authigenic carbonate

180 precipitation during remineralization of organic carbon in marine pore fluids, in contrast to

181 recrystallization of carbonate precursors (Loyd et al., 2013).

182 3. Methods

183 Iodine-to-calcium-magnesium ratios and magnesium-to-calcium ratios were measured at

184 Syracuse University using a Bruker M90 quadrupole inductively-coupled-plasma mass

185 spectrometer (ICP-MS) and at the University of California, Riverside, using a Agilent 7900c ICP-

186 MS, according to standard methods (Hardisty et al., 2014; Lu et al., 2016; Lu et al., 2010; Zhou et

187 al., 2015; Zhou et al., 2014). All samples from the Clino and Unda cores and the Monterey and

188 Tieling formations were measured at UC Riverside and the remainder at Syracuse University.

189 Approximately 3-5 mg of powdered carbonate was used for each analysis. Samples were

190 sonicated in $1 \mathrm{~mL}$ DI water that was then centrifuged and decanted. Following this, $3 \% \mathrm{HNO}_{3}$

191 was added to each sample allowing for complete dissolution of all carbonate, and these were 
192 similarly sonicated for $\sim 10$ minutes and centrifuged. The supernatant was diluted in a matrix with

193 combinations of nitric acid and an iodine-stabilizing solution (tertiary amine or tetramethyl

194 ammonium hydroxide) to obtain $\mathrm{Ca}$ concentrations of approximately $50 \mathrm{ppm}$. Calibration

195 standards were made fresh each day from powdered potassium iodate in a similar matrix with the

196 addition of $50 \mathrm{ppm} \mathrm{Ca}$. The coral standard JCP-1 was analyzed intermittently with average values

197 at Syracuse University and UC Riverside that were identical within error.

198 The mineralogical determinations for the Clino and Unda cores, Monterey, Key Largo,

199 and Bahamas Bank top cores were performed at the University of Miami using a Panalytical X-

200 Pert Pro via a method published previously (Melim et al., 1995). The associated error is \pm 2 wt.

$201 \%$. Carbon and oxygen isotope values for the Johnnie Formation, the Clino and Unda cores, and

202 portions of the GBB short cores were measured at the University of California, Riverside, using a

203 GasBench II interface coupled, via continuous flow, to a Delta V Thermo Advantage IRMS

204 (Isotope Ratio Mass Spectrometer). Carbon and oxygen isotope values for the C1, C4, C6, and C7

205 Bahamas Bank top cores were analyzed at The Center for Stable Isotope Biogeochemistry at UC,

206 Berkeley, using a MultiCarb system connected with a GV IsoPrime mass spectrometer in dual

207 inlet mode. Carbon and oxygen isotopes for the Doushantuo Formation were measured at the

208 University of Nevada, Las Vegas, using a Kiel IV carbonate device connected to a Finnigan Delta

209 V Plus mass spectrometer in dual inlet mode. All values are presented in the standard delta

210 notation as per mil (\%) deviation from Vienna Pee Dee Belemnite (V-PDB), with replicate

211 standard analyses yielding standard deviations typically better than $0.10 \%$ for carbon and

212 oxygen isotopes.

\section{4. Results}

214 The highest $\mathrm{I} /(\mathrm{Ca}+\mathrm{Mg})$ values in our Neogene-Quaternary samples, ranging from 6.0-

$215 \quad 11.6 \mu \mathrm{mol} / \mathrm{mol}$, are found in predominantly aragonite and HMC samples from bank-top cores

216 from the well-oxygenated GBB (Table 3). The Key Largo coral heads contain $\mathrm{I} /(\mathrm{Ca}+\mathrm{Mg}$ ) values 
217 that show little change across the meteoric fluid-driven aragonite-to-calcite mineralogy transition,

218 with only KL-11 containing samples with decreased iodine contents in some, but not all, LMC-

219 dominated samples (Fig. 2). For cores Clino and Unda, the carbon and oxygen isotopic and

220 mineralogical trends and values within specific intervals are generally consistent with that of

221 previous work of different samples from the same core (e.g., Melim et al., 1995; Swart and

222 Melim, 2000; Swart and Kennedy, 2012), including the negative $\delta^{13} \mathrm{C}_{\text {carb }}$ excursion characterizing

223 the meteoric zone in the Clino core (Fig. 3). The Clino core contains $\mathrm{I} /(\mathrm{Ca}+\mathrm{Mg})$ ranging from

224 below detection to $5.71 \mu \mathrm{mol} / \mathrm{mol}$. The highest $\mathrm{I} /(\mathrm{Ca}+\mathrm{Mg})$ values overlap with intervals

225 containing relatively higher aragonite content, with most LMC- and dolomite-dominated intervals

226 generally containing relatively lower $\mathrm{I} /(\mathrm{Ca}+\mathrm{Mg})$ ratios (Fig. 4). The Unda and Monterey samples

227 have $\mathrm{I} /(\mathrm{Ca}+\mathrm{Mg})$ values ranging from below detection to 0.46 and $1.01 \mu \mathrm{mol} / \mathrm{mol}$, respectively

228 (Fig. 4). Of the samples containing greater than $20 \mathrm{wt} . \%$ dolomite, $\mathrm{I} /(\mathrm{Ca}+\mathrm{Mg})$ ratios are $<0.46$

229 and $0.40 \mu \mathrm{mol} / \mathrm{mol}$ for the Monterey Formation and the Unda core, respectively, with most values

230 below detection.

231 Our Proterozoic samples contain both dolomite and limestone (Fig. 5), and iodine is

232 present in some of the samples from nearly all the units evaluated (Fig. 6). Proterozoic $\mathrm{I} /(\mathrm{Ca}+\mathrm{Mg}$ )

233 ratios from carbonates older than the late Ediacaran Shuram anomaly are $\leq 2.8 \mu \mathrm{mol} / \mathrm{mol}$ and are

234 often much less - notably within the range observed in primary carbonate from modern low-

235 oxygen settings (yellow squares, Fig. 6). There is a drop in maximum $\mathrm{I} /(\mathrm{Ca}+\mathrm{Mg})$ to $\leq 0.8$

$236 \mu \mathrm{mol} / \mathrm{mol}$ around $\sim 2.0 \mathrm{Ga}$, following the Lomagundi positive carbon isotope excursion (LE; 2.2-

$2372.1 \mathrm{Ga}$ ). In the following interval, from 2.0 to $1.0 \mathrm{Ga}$, maximum values of $\leq 0.8 \mu \mathrm{mol} / \mathrm{mol}$ are

238 found in 13 of the 14 studied units with the only exception being the Tieling Formation of North

239 China, where maximum $\mathrm{I} /(\mathrm{Ca}+\mathrm{Mg})$ ratios are similar to those characterizing the $\mathrm{LE}$ and early

240 Neoproterozoic (Fig. 6). Starting at roughly $1.0 \mathrm{Ga}$, maximum values are more frequently

241 elevated relative to the mid-Proterozoic. Lastly, all four of our Ediacaran, Shuram-age sections

242 show a marked increase in $\mathrm{I} /\left(\mathrm{Ca}+\mathrm{Mg}\right.$ ) in phase with the dramatic decrease in $\delta^{13} \mathrm{C}_{\text {carb }}$ (Fig. 7). 


\section{5. Discussion}

\subsection{Iodine behavior in response to Neogene-Quaternary carbonate diagenesis}

245 No previous study has measured carbonate iodine contents within an independently 246 established framework of well-constrained diagenetic alteration. Interpretation of iodine contents

247 of water column-derived calcitic foraminifera is obviously ideal; however, this is not always

248 possible in ancient samples. Multiple previous studies have instead measured bulk iodine in

249 ancient carbonate (Hardisty et al., 2014; Loope et al., 2013; Zhou et al., 2015; Owens et al.,

250 2017). Below we provide a context for interpreting our Proterozoic bulk carbonate data through a

251 process-oriented perspective in Neogene-Quaternary carbonate of the Bahamas and Monterey

252 Formation that progresses from modern carbonate precipitation to deposition, burial, and

253 subsequent variable styles of diagenetic mineral transformation. With the exception of the

254 Monterey Formation, the waters that hosted primary carbonate precipitation are constrained to

255 have been well oxygenated, which implies that presently low and highly variable $\mathrm{I} /(\mathrm{Ca}+\mathrm{Mg})$

256 ratios do not record shifts in the $\mathrm{IO}_{3}{ }^{-}$content of the local waters of deposition. Instead, low

$257 \mathrm{I} /(\mathrm{Ca}+\mathrm{Mg})$ values or variations likely track secondary processes related to depositional setting,

258 mineralogy, and related diagenetic overprinting of primary values.

259 The highest $\mathrm{I} /(\mathrm{Ca}+\mathrm{Mg})$ ratios in our Neogene-Quaternary sample set come from the GBB

260 bank-top cores (Table 3), which is the least altered sample set of this study and representative of

261 the carbonate iodine signature of initial deposition. The range in $\mathrm{I} /(\mathrm{Ca}+\mathrm{Mg})$ values from bulk

262 aragonite-HMC in all the GBB bank-top core samples $(6.0-11.6 \mu \mathrm{mol} / \mathrm{mol}$; Table 3$)$ is higher

263 than that found in LMC foraminifera, which in previous studies of well-oxygenated settings spans

264 from 4-7 $\mu \mathrm{mol} / \mathrm{mol}(\mathrm{Lu}$ et al., 2016). None of our $\mathrm{I} /(\mathrm{Ca}+\mathrm{Mg})$ profiles from any of the seven GBB

265 short cores increases with depth (Table 3; Supplementary Fig. 2), indicating that the elevated

$266 \mathrm{I} /(\mathrm{Ca}+\mathrm{Mg})$ values are unrelated to post-burial processes. Uncertainties surrounding partition

267 coefficients for HMC and aragonite relative to that of calcite and potential vital effects associated

268 with uncharacterized skeletal debris may lead to errors in the estimated $\mathrm{IO}_{3}{ }^{-}$content of ambient 
269 waters from variable carbonate mineralogies. Until the partition coefficients of iodine for 270 individual carbonate mineralogies are resolved, caution should be taken in comparing absolute $271 \mathrm{I} /(\mathrm{Ca}+\mathrm{Mg})$ ratios between samples of mixed or unknown carbonate mineralogy. For example, if 272 we apply the partition coefficients from laboratory LMC precipitation experiments (Lu et al., 273 2010; Zhou et al., 2014) to the $\mathrm{I} /(\mathrm{Ca}+\mathrm{Mg})$ ratios from our aragonite- and HMC-dominated GBB 274 carbonate, we predict local marine $\mathrm{IO}_{3}{ }^{-}$abundance from $\sim 600 \mathrm{nM}$ to approaching $1 \mu \mathrm{M}$, which is 275 not consistent with the typical range observed in marine, surface waters (roughly 300 to $450 \mathrm{nM}$;

276 Chance et al., 2014). However, the wide and elevated range in $\mathrm{I} /(\mathrm{Ca}+\mathrm{Mg})$ from the $\mathrm{GBB}$ is not 277 easily attributed to any one factor, as the $\mathrm{GBB} \mathrm{I} /(\mathrm{Ca}+\mathrm{Mg})$ ratios differ even between adjacent 278 oolitic shoals of similar composition and show no clear co-variation with mineralogy, $\delta^{13} \mathrm{C}_{\mathrm{carb}}$, or 279 modern depositional setting (Table 3; Supplementary Fig. 2). Regardless, our observations are 280 consistent with previous works indicating that the $\mathrm{I} /(\mathrm{Ca}+\mathrm{Mg})$ ratios of primary carbonate 281 minerals precipitated from well-oxygenated seawater do not overlap with the $0-2.6 \mu \mathrm{mol} / \mathrm{mol}$ 282 values observed for calcitic foraminifera living within low-oxygen settings (Glock et al., 2014; 283 Lu et al., 2016).

284 The Key Largo coral heads provide a case study specific to initial aragonite precipitation 285 and post-depositional meteoric aragonite-to-calcite neomorphism during subaerial carbonate 286 exposure (Gill et al., 2008). In this case, the $\mathrm{I} /(\mathrm{Ca}+\mathrm{Mg})$ ratios of primary aragonite fall within the 287 range reported for LMC foraminifera from well-oxygenated settings (Fig. 2). Previous work from 288 these same samples has shown that lower dissolved elemental abundances (e.g., S, Sr) in fresh 289 (meteoric) waters versus seawater, which to a lesser extent is also true of iodine (Fehn, 2012), 290 lead to decreases in their concentrations in diagenetic LMC relative to primary aragonite (Gill et 291 al., 2008). Opposite of this expectation, however, the primary $\mathrm{I} /(\mathrm{Ca}+\mathrm{Mg})$ ratios generally change 292 little across the aragonite-to-calcite transitions of our samples. The only exception is a LMC 293 interval directly at the reaction front of $\mathrm{KL}-11$ that contains lower $\mathrm{I} /(\mathrm{Ca}+\mathrm{Mg})$ relative to the 294 primary aragonite (Fig. 2), but there are no discernable differences between these and other LMC 
295 samples with relatively elevated $\mathrm{I} /(\mathrm{Ca}+\mathrm{Mg})$. The maintenance of high, primary $\mathrm{I} /(\mathrm{Ca}+\mathrm{Mg})$ ratios 296 during meteoric diagenesis in the Key Largo samples may represent a special case where oxic 297 diagenetic conditions allowed for the iodine content of the primary aragonite to (at least 298 temporarily) buffer iodine contents of the diagenetic LMC. Sulfate reduction is known to partially 299 promote aragonite-to-calcite neomorphism during meteoric diagenesis in the Bahamas (McClain 300 et al., 1992) — conditions where iodine would be present primarily as $\mathrm{I}^{-}$. However, the $\delta^{34} \mathrm{~S}$ values

301 of carbonate-associated sulfate (CAS) in both our original aragonite and secondary LMC Key

302 Largo samples are similar to those of Pleistocene/modern seawater sulfate (Gill et al., 2008),

303 arguing against substantial sulfate reduction during meteoric diagenesis. Nonetheless, the Key

304 Largo profiles support that $\mathrm{I} /(\mathrm{Ca}+\mathrm{Mg})$ ratios have the potential to be maintained, but are unlikely

305 to increase following deposition and neomorphism driven by diagenesis in meteoric fluids.

306 The Clino core best illustrates the range in diagenetic zones and related geochemical and 307 mineralogical variability possible from the GBB (Figs. 3, 4). The diagenetic zones reflect a 308 temporal transition from a slope to a platform depositional setting during the Neogene309 Quaternary, with a negative $\delta^{13} \mathrm{C}_{\text {carb }}$ excursion in the upper portion due to multiple periods of 310 subaerial exposure and subsequent aragonite-to-calcite neomorphism within meteoric fluids

311 (Melim et al., 1995; Swart and Melim, 2000). Below this depth, aragonite-to-calcite 312 neomorphism and minor dolomitization occurred exclusively in marine pore waters (Melim et al., 313 1995; Swart and Melim, 2000). The $\mathrm{I} /(\mathrm{Ca}+\mathrm{Mg})$ ratios from the aragonite-HMC GBB short cores 314 and aragonitic portions of the Key Largo Limestone are most like those expected for primary $315 \mathrm{I} /(\mathrm{Ca}+\mathrm{Mg})$ ratios from the Bahamian Clino core (i.e., $\mathrm{I} /(\mathrm{Ca}+\mathrm{Mg})>3 \mu \mathrm{mol} / \mathrm{mol})$. Indeed, although 316 the Clino core sample set no longer contains intervals with $100 \%$ aragonite and has only sparse $317 \mathrm{HMC}$, the samples with higher aragonite contents do generally contain the $\mathrm{I} /(\mathrm{Ca}+\mathrm{Mg})$ ratios that 318 are above those observed from low-oxygen depositional settings (Figs. 3, 4a). However, the core 319 shows clear diagenetic iodine loss in secondary LMC and dolomite phases, as most of the Clino 320 core $\mathrm{I} /(\mathrm{Ca}+\mathrm{Mg})$ ratios overlap with the $<2.6 \mu \mathrm{mol} / \mathrm{mol}$ values observed from low-oxygen marine 
321 settings. The ratios show no distinct trends with $\delta^{13} \mathrm{C}_{\text {carb }}$, with regard to diagenetic zones, specific

322 to lithology, or across the facies transitions (Fig. 3). Instead, the inferred decreases in $\mathrm{I} /(\mathrm{Ca}+\mathrm{Mg}$ )

323 ratios during diagenesis in the Clino core are consistent with previous inferences for

324 neomorphism of aragonite and HMC to LMC and dolomite in pore waters hosting significant

325 sulfate reduction and closed to seawater exchange (Swart and Melim, 2000). Despite initial

326 deposition in a well-oxygenated setting with temporally varying facies likely hosting a large array

327 of high primary $\mathrm{I} /(\mathrm{Ca}+\mathrm{Mg})$ ratios, we surmise that progressive diagenesis will ultimately decrease

328 ratios to relatively low values within a small range for the entire core. This includes the currently

329 high $\mathrm{I} /(\mathrm{Ca}+\mathrm{Mg})$ values in the aragonitic intervals near the top and bottom of our sampled profile.

330 These observations imply that there is likely much overlap between ranges in $\mathrm{I} /(\mathrm{Ca}+\mathrm{Mg})$ from

331 carbonate precipitated from low oxygen and anoxic water columns and secondary carbonate

332 phases precipitated in low oxygen or anoxic pore waters (Figure 3d). When possible,

333 measurement of $\mathrm{I} /(\mathrm{Ca}+\mathrm{Mg})$ from calcite with independent constraints as representing primary

334 carbonate phases will be ideal.

335 The samples from the Unda core and Monterey concretions were specifically selected to

336 provide constraints on iodine contents in dolomites that are well constrained to have precipitated

337 within marine pore waters (Fig. 4b). Our samples from the Unda core contain $100 \%$ dolomite in

338 many cases, which previous studies have linked to reefal sediments that experienced aragonite-to-

339 LMC neomorphism in marine pore fluids prior to dolomitization (Swart and Melim, 2000).

340 Dolomite concretions of the Monterey Formation were largely not derived from neomorphism of

341 primary marine carbonate. Instead, they represent authigenic dolomite precipitated in phase with

342 extensive pore water alkalinity production during remineralization in organic-rich sediments

343 marked by anoxic pore fluids closed to exchange with seawater (Blättler et al., 2015; Loyd et al.,

344 2012). Despite the very different mechanisms of dolomite precipitation, the two diagenetic

345 dolomite sample sets reveal similar results, yielding the lowest $\mathrm{I} /(\mathrm{Ca}+\mathrm{Mg})$ ratios of our entire

346 diagenetic data set. Most values are below detection, and the highest value is $0.46 \mu \mathrm{mol} / \mathrm{mol}$. We 
347 suggest that the extremely low values reflect multiple generations of diagenetic mineral 348 transformation for dolomites of the Unda core and anoxic diagenetic conditions in both cases.

349 The presence of iodine in some Monterey dolomite samples may indicate minor contributions

350 from recrystallization of primary carbonate that initially contained some iodine. The low

$351 \mathrm{I} /(\mathrm{Ca}+\mathrm{Mg})$ values from both dolomite sample sets are not likely to completely reflect differences

352 in partition coefficients for dolomite relative to LMC (though this has yet to be resolved), as

353 many Proterozoic dolomites from this study have high ratios relative to the Neogene sample set

354 (discussed in the next section; Fig. 5). Ultimately, our results reveal that dolomitization of

355 carbonate precursors and authigenic dolomite precipitation in marine pore fluids will dramatically

356 lower $\mathrm{I} /(\mathrm{Ca}+\mathrm{Mg})$ ratios from that characteristic of primary carbonate formed in well-oxygenated

357 water columns. Without proper caution, low dolomite ratios could lead to underestimation of $\mathrm{IO}_{3}{ }^{-}$

358 and hence the $\mathrm{O}_{2}$ availability in the overlying water column. In carbonates characterized by

359 ubiquitous dolomite, independent geochemical constraints on the redox state (e.g., $\left.\delta^{34} \mathrm{~S}_{\mathrm{CAS}}\right)$ and

360 the extent of exchange with seawater (e.g., $\mathrm{Ca}$ and $\mathrm{Mg}$ isotopes) during dolomite precipitation

361 may provide the most ideal context for determining the confidence in which $\mathrm{I} /(\mathrm{Ca}+\mathrm{Mg})$ ratios

362 reflect water column or diagenetic chemistry.

\subsection{Neogene-Quaternary perspectives on Proterozoic carbonate diagenesis}

364 Our proxy validation efforts with the Neogene-Quaternary samples indicate that

$365 \mathrm{I} /(\mathrm{Ca}+\mathrm{Mg})$ ratios should not increase during diagenesis in reducing pore fluids. Given this

366 observation, the simple presence of iodine in ancient carbonate is a robust fingerprint of oxic

367 conditions. Again, 'false positives' are not anticipated and have not been observed in young

368 sediments. Iodine's redox behavior distinguishes it from other common paleoredox proxies (e.g.,

369 Fe speciation, S isotopes and concentrations, and Mo and U concentrations), which specifically

370 fingerprint local anoxic water columns and are most commonly applied to deeper basinal shales.

371 Beyond the simple presence-absence of surface ocean $\mathrm{O}_{2}$, detailed comparison of Proterozoic 
$372 \mathrm{I} /(\mathrm{Ca}+\mathrm{Mg})$ trends to Neogene-Quaternary diagenetic carbonate and dolomite support that

373 Proterozoic temporal trends may reflect seawater redox evolution, including relative changes in

374 the depth of anoxic waters relative to that of carbonate precipitation, when interpreted with

375 appropriate caution. For instance, there are no known temporal variations in diagenesis that

376 would cause the observed first-order, long-term patterns through the Precambrian and

377 preferentially favor the persistence of generally low maximum values during the mid-Proterozoic

378 and the absence of iodine in Archean samples (Fig. 6).

379 An additional, valuable case study in our effort to distinguish seawater versus pore water

380 origins for Proterozoic $\mathrm{I} /(\mathrm{Ca}+\mathrm{Mg})$ signal comes from a comparison between the $\mathrm{I} /(\mathrm{Ca}+\mathrm{Mg})$ trends

381 spanning the Shuram negative $\delta^{13} \mathrm{C}_{\text {carb }}$ anomaly (Fig. 7) and our sample set recording Neogene-

382 Quaternary diagenesis, most notably that linked to the negative $\delta^{13} \mathrm{C}_{\text {carb }}$ values of the Clino core

383 (Fig. 3). Both meteoric and marine diagenesis have been invoked to explain the extremely

384 negative $\delta^{13} \mathrm{C}_{\text {carb }}$ values of the Shuram anomaly and other negative Neoproterozoic $\delta^{13} \mathrm{C}_{\text {carb }}$

385 excursions (Schrag et al., 2013; Swart and Kennedy, 2012), with the Shuram carbon isotope

386 values trending from +5 to $-12 \%$ (Fig. 7). The meteorically driven negative $\delta^{13} \mathrm{C}_{\text {carb }}$ excursion of

387 the Clino core has specifically been invoked to suggest the possibility that ancient negative

$388 \delta^{13} \mathrm{C}_{\text {carb }}$ excursions are products of diagenesis rather than secular evolution of the global carbon

389 cycle (Swart and Kennedy, 2012). If diagenetic, the Shuram $\delta^{13} \mathrm{C}_{\text {carb }}$ data would most likely

390 reflect post-depositional mineralogical transformations and the associated low $\delta^{13} \mathrm{C}$ values of

391 dissolved inorganic carbon produced in pore fluids during organic matter remineralization under

392 anoxic or reducing subsurface conditions. Our iodine data from the Clino core and other

393 Neogene-Quaternary sediments confirm that $\mathrm{I} /(\mathrm{Ca}+\mathrm{Mg})$ values do not increase during diagenesis

394 and show no relationship with $\delta^{13} \mathrm{C}_{\text {carb }}$ (Fig. 2), as $\mathrm{IO}_{3}{ }^{-}$is quantitatively reduced under the anoxic

395 conditions typical of diagenetic carbonate precipitation (Kennedy and Elderfield, 1987a; Kennedy

396 and Elderfield, 1987b). In contrast, however, $\mathrm{I} /(\mathrm{Ca}+\mathrm{Mg})$ ratios across the Shuram excursion, at

397 each of our four paleogeographically distant localities, increase in parallel with decreasing 
$398 \delta^{13} \mathrm{C}_{\text {carb }}$ values and do so consistently despite variable mineralogy and sedimentary facies (Fig. 7).

399 Notably, the maximum observed $\mathrm{I} /(\mathrm{Ca}+\mathrm{Mg})$ ratios vary among the Shuram sections, which could

400 be the result of spatially variable, redox-driven local water column $\mathrm{IO}_{3}{ }^{-}$concentrations or a range

401 of secondary factors that can lower the values in different ways (see diagenesis discussion).

402 Regardless, the observed stratigraphic increase in $\mathrm{I} /(\mathrm{Ca}+\mathrm{Mg})$ ratios at all four locations in phase

403 with the falling $\delta^{13} \mathrm{C}_{\text {carb }}$ limb of the Shuram anomaly is the opposite of the pattern expected with

404 diagenesis (Figs. 2, 3, 4). Collectively, these data support the likelihood that the Shuram anomaly

405 at least partially captures local seawater availability of $\mathrm{IO}_{3}{ }^{-}$and is a primary $\delta^{13} \mathrm{C}$ feature tracking

406 trends, likely global, in seawater chemistry. A primary contribution to the Shuram anomaly is

407 further braced by records of CAS (Kaufman et al., 2007; Loyd et al., 2013; Osburn et al., 2015),

$408 \mathrm{U}$ concentrations (Zhao et al., 2016), detailed Ca-Mg-C isotope comparisons (Husson et al.,

409 2015), and compound-specific $\delta^{13} \mathrm{C}$ values of organic carbon (Lee et al., 2015), all of which show

410 trends counter to those expected from diagenetic alteration.

411 Lastly, dolomitization in Proterozoic samples is not necessarily a source of false secular

412 trends or, more generally, a fingerprint of severely altered samples not recording signals of

413 primary ocean chemistry. Instead, previous workers have argued from a combination of retention

414 of primary sedimentary fabrics (Fairchild et al., 1991; Kah, 2000; Tucker, 1982), geochemical

415 data (Husson et al., 2015; Kah, 2000; Tucker, 1982), and petrographic evidence (Tucker, 1982;

416 van Smeerdijk Hood et al., 2011) that many dolomites formed penecontemporaneously with

417 deposition in the Proterozoic, in open exchange with seawater, and potentially at or near the

418 sediment-water interface. We do acknowledge that stoichiometrically disordered dolomite is

419 subject to continued maturation during diagenesis (Vahrenkamp and Swart, 1994). Still, one

420 implication is that the long-term stability of dolomite relative to other carbonate phases could

421 mean that Proterozoic early diagenetic dolomite, even if replacive, may be a stronger and even

422 preferred geochemical archive of ancient marine conditions relative to stratigraphically associated

423 limestone subject to diagenetic alteration during neomorphism. A comparison of iodine data from 
424 our Neogene diagenetic dolomite from the Bahamas and Monterey to Proterozoic samples further

425 reinforces the potential frequency and benefit of early Proterozoic dolomite and points to

426 processes regulating $\mathrm{I} /(\mathrm{Ca}+\mathrm{Mg})$ ratios other than dolomitization in some of our samples (Fig. 5).

427 Specifically, the highest $\mathrm{I} /(\mathrm{Ca}+\mathrm{Mg})$ ratios from our Proterozoic carbonates are found often in

428 dolomite - a trend opposite to that seen in our Neogene samples. Late-stage diagenetic processes,

429 such as interaction with anoxic brines (e.g., Derry, 2010), provide an unlikely explanation for the

430 elevated $\mathrm{I} /(\mathrm{Ca}+\mathrm{Mg})$ ratios in our Proterozoic dolomite, as these fluids would not support elevated

$431 \mathrm{IO}_{3}^{-}$contents. Given the early redox sensitivity of $\mathrm{IO}_{3}^{-}$reduction with declining $\left[\mathrm{O}_{2}\right]$, our data

432 reinforce the idea that in some cases Proterozoic dolomite precipitation likely occurred near or at

433 the sediment-water interface and hence should record at least partial seawater signals (cf.,

434 Fairchild et al., 1991; Kah, 2000; Tucker, 1982; van Smeerdijk Hood et al., 2011).

435 Given the combination of observations here and in previous work, broad first-order

436 temporal trends in maximum $\mathrm{I} /(\mathrm{Ca}+\mathrm{Mg})$ ratios are cautiously considered in discussions below as

437 records of shallow ocean redox evolution. We emphasize again that our combined diagenetic data

438 explicitly reveal that post-depositional increases in $\mathrm{I} /(\mathrm{Ca}+\mathrm{Mg})$ are unlikely, and hence, if

439 anything, the maximum $\mathrm{I} /(\mathrm{Ca}+\mathrm{Mg})$ value from a given section is a minimum estimate of local

440 seawater $\mathrm{IO}_{3}{ }^{-}$availability. While we are not linking $\mathrm{I} /(\mathrm{Ca}+\mathrm{Mg})$ ratios to a specific seawater $\mathrm{IO}_{3}{ }^{-}$

441 concentration, we do maintain that the first-order trends over billions of years are difficult to

442 attribute to secondary effects.

\section{$443 \quad 5.3$ Comparing the modern and Proterozoic marine iodine reservoir}

444 Our temporal $\mathrm{I} /(\mathrm{Ca}+\mathrm{Mg})$ record in Figure 6 suggests the likelihood of changes in marine

$445 \mathrm{IO}_{3}{ }^{-}$concentrations through time. Modern settings indicate that the control responsible for the

446 largest shifts in local marine $\mathrm{IO}_{3}{ }^{-}$concentration is the local redox state (Fig. 1; Emerson et al.,

447 1979; Farrenkopf and Luther III, 2002; Rue et al., 1997; Wong and Brewer, 1977); however,

448 changes in the size of the total marine dissolved iodine reservoir (both $\mathrm{IO}_{3}{ }^{-}$and $\mathrm{I}^{-}$) could also

449 control $\mathrm{IO}_{3}{ }^{-}$concentrations if oxic conditions prevailed. We consider this possibility below. 
451 of the Phanerozoic as a whole due to the absence or limited role of algal primary production and

452 burial in marine sediments during the Precambrian. Marine sediments and sedimentary rocks are

453 estimated to host as much as $\sim 96 \%$ of crustal iodine, with the remaining fraction present in the

454 hydrosphere and igneous and metamorphic rocks (Muramatsu and Wedepohl, 1998). Algae,

455 particularly brown algae, host the largest iodine enrichments in any known natural material by

456 orders of magnitude, significantly contributing to iodine enrichment in organic-rich sediments

457 (Muramatsu and Wedepohl, 1998), which is recycled back to the ocean during weathering,

458 diagenesis, and subduction (Fehn, 2012; Lu et al., 2010). Importantly, the first fossil evidence for

459 algae does not appear until the late Mesoproterozoic (reviewed in Knoll, 2014), and records of

460 algal-derived sterane biomarkers — representing eukaryotes — do not support algae being dominant

461 contributors to marine organic matter until the latest Proterozoic (e.g., Brocks et al., 2016).

462 Relatively small iodine sinks in both Proterozoic sedimentary organic matter and carbonate (see

463 Fig. 6) point to a likely larger Proterozoic seawater iodine reservoir relative to today. These

464 observations imply that our finding of low $\mathrm{I} /(\mathrm{Ca}+\mathrm{Mg})$ in the Precambrian relative to the modern

465 carbonates is unlikely to reflect a smaller marine reservoir of total dissolved iodine or shifts in

466 that pool, but instead derive from lower marine $\mathrm{IO}_{3}{ }^{-}$concentrations at the site of carbonate

467 precipitation related primarily to local redox.

468 For the Shuram anomaly specifically, we speculate that the oxidation of algae-derived

469 organic matter could drive a temporally isolated increase in the total dissolved marine iodine

470 reservoir. Oxidation of organic matter, as suggested in previous studies (Rothman et al., 2003;

471 Fike et al., 2006; Kaufman et al., 2007), also provides a mechanism for the input of isotopically

472 light DIC into the ocean to produce the negative $\delta^{13} \mathrm{C}_{\text {carb }}$ characteristic of the Shuram excursion.

473 For instance, simple mass balance calculations suggest that the input of DIC from organic carbon

474 oxidation (with a $\delta^{13} \mathrm{C}$ of $-25 \%$ ) necessary to drive a whole-ocean $-17 \% \delta^{13} \mathrm{C}$ excursion 
475 (equivalent to that often inferred for the Shuram anomaly) in the modern ocean would increase

476 the total marine dissolved iodine reservoir by a factor of $\sim 1.6$ (using the typical algae I/TOC ratio

477 of $\left.10^{-4}\right)$. However, given that $\mathrm{I} /(\mathrm{Ca}+\mathrm{Mg})$ tracks $\mathrm{IO}_{3}{ }^{-}$and not total iodine, it is unlikely that the

478 Shuram increase in $\mathrm{I} /(\mathrm{Ca}+\mathrm{Mg})$ is simply a product of an increase in the total marine iodine

479 reservoir. For example, regardless of an increase in the total iodine reservoir, $\mathrm{IO}_{3}{ }^{-}$concentrations

480 (and hence $\mathrm{I} /(\mathrm{Ca}+\mathrm{Mg}$ ) ratios) would decrease (the opposite of what is observed) during the

481 excursion if oxidation of reduced carbon acted to simultaneously expand anoxia (Lu et al., 2010;

482 Zhou et al., 2015). We suggest instead that an increase in marine $\mathrm{IO}_{3}{ }^{-}$through the Shuram

483 anomaly would also require an expansion of oxic settings at least in the shallow ocean.

484 Supporting this, S concentrations and isotope data for CAS through the Shuram anomaly provide

485 evidence for an increase in marine sulfate concentrations and hence a general expansion of

486 oxidizing conditions in the same settings recording increased $\mathrm{IO}_{3}{ }^{-}$abundance from $\mathrm{I} /(\mathrm{Ca}+\mathrm{Mg})$

487 ratios (Fike et al., 2006; Kaufman et al., 2007; Loyd et al., 2013; Osburn et al., 2015).

488 Importantly, however, our iodine data do not demand that an oxidation event driving the negative

$489 \delta^{13} \mathrm{C}_{\text {carb }}$ excursion was linked to deep ocean ventilation. Oxygenation may instead have been

490 limited to near-surface settings. Redox stratification through the Shuram anomaly is supported by

491 decreased $\mathrm{I} /(\mathrm{Ca}+\mathrm{Mg})$ ratios following the event and thus an inferred return to more reducing

492 conditions in the ocean (Fig. 7c), geochemical studies suggesting widespread anoxia before and

493 after the excursion (e.g., Johnston et al., 2013; Sperling et al., 2015), as well as mass balance

494 calculations highlighting the challenges of maintaining the oxidants necessary to drive the $\delta^{13} \mathrm{C}$

495 excursion if it reflects whole-ocean ventilation (Bristow and Kennedy, 2008). Explaining the

496 origin of the Shuram $\delta^{13} \mathrm{C}_{\text {carb }}$ excursion remains a challenge; however, future models should

497 consider the growing evidence for spatiotemporally limited oxidation specific to shallow settings

498 at the onset of the excursion. 
500 In light of our study of diagenetic effects in recent carbonates, the simple presence of

501 iodine in most of the Proterozoic carbonate units we analyzed provides strong evidence for

502 surface ocean $\left[\mathrm{O}_{2}\right]$ above the low threshold required for $\mathrm{IO}_{3}{ }^{-}$accumulation. Previous studies have

503 argued for an $\left[\mathrm{O}_{2}\right]$ requirement of at least 1-3 $\mu \mathrm{M}$ for marine $\mathrm{IO}_{3}{ }^{-}$accumulation and the presence

504 of carbonate-bound iodine (Hardisty et al., 2014). Further support for Proterozoic surface ocean

$505\left[\mathrm{O}_{2}\right]$ at or above low $\mu \mathrm{M}$ levels comes from the fossil evidence for the presence of eukaryotic

506 microfossils in mid-Proterozoic oceans (Knoll, 2014), as well as from modeling efforts indicating

507 the potential for single digit $\mu \mathrm{M}$ surface ocean $\mathrm{O}_{2}$ concentrations from in situ oxygenic

508 photosynthesis under even a completely anoxic atmosphere (Reinhard et al., 2016). Importantly,

509 the $>1-3 \mu \mathrm{M} \mathrm{O}_{2}$ levels inferred for the Proterozoic surface ocean are above those predicted from

510 equilibrium calculations, assuming the very low mid-Proterozoic atmospheric $p \mathrm{O}_{2}(<0.1-1 \%$

511 PAL) suggested recently by $\mathrm{Cr}$ isotope measurements (Fig. 6; Cole et al., 2016; Crowe et al.,

512 2013; Planavsky et al., 2014), Collectively, the two proxies may provide evidence for a

513 disequilibrium between the atmosphere and surface ocean favored by in situ photosynthetic

514 oxygen production in the shallow waters (Reinhard et al., 2016). Alternatively, the apparent

515 discrepancy could reflect the uncertainties in our current understanding of modern iodine (Chance

516 et al., 2014; Luther III et al., 1995) and chromium cycling (compare Gilleaudeau et al., 2016 and

517 Planavsky et al., 2014).

$518 \mathrm{I} /(\mathrm{Ca}+\mathrm{Mg})$ ratios also provide new constraints on the degree of mixing of near-surface

519 oxic waters with shallow anoxic waters (Lu et al., 2016). Given the consistently low maximum

$520 \mathrm{I} /(\mathrm{Ca}+\mathrm{Mg})$ ratios observed through most of the Proterozoic relative to the Phanerozoic (Fig. 6),

521 we suggest that the iodine record most strongly supports a weakly oxidized surface ocean with

522 shallow anoxic waters near or within the surface ocean for most of the Proterozoic. In other

523 words, Proterozoic surface ocean redox was analogous to the oxycline of modern anoxic basins 
524 and OMZs (Fig. 1). These modern settings — where oxygen is locally present, but $\mathrm{IO}_{3}{ }^{-}$reduction is 525 active in resident and/or adjacent exchanging water masses-are characterized by sustained $\mathrm{IO}_{3}{ }^{-}$ 526 accumulation, but with diagnostically low concentrations and correspondingly low $\mathrm{I} /(\mathrm{Ca}+\mathrm{Mg})$ 527 ratios in the range observed throughout the Proterozoic (yellow squares, Fig. 6). That pattern 528 manifests in a predominance of low $\mathrm{I} /(\mathrm{Ca}+\mathrm{Mg})$ ratios during the Proterozoic interrupted only 529 episodically by largely minor increases (Fig. 6) during some intervals previously described as 530 oxygenation events. These include the GOE (Lyons et al., 2014), the Lomagundi excursion (Fig.

531 6; Bekker and Holland, 2012), at 1.4 Ga (Mukherjee and Large, 2016), the Neoproterozoic 532 broadly (Planavsky et al., 2014), and the Shuram anomaly (Fike et al., 2006). Collectively, these

533 trends suggest a history of protracted and dynamic oxygenation within a largely anoxic ocean

534 (Reinhard et al., 2013; Sperling et al., 2015) through the Proterozoic — rather than a unidirectional 535 rise.

536 We specifically link the generally low but non-zero mid-Proterozoic iodine values to an 537 extremely shallow oxycline that facilitated direct advective exchange between weakly oxic 538 surface waters and underlying or adjacent waters that were dominantly anoxic (Reinhard et al., 539 2013; Sperling et al., 2015). Reinforcing this interpretation, mid-Proterozoic records of chromium 540 isotopes (Planavsky et al., 2014), Mo and $\mathrm{Cr}$ concentrations (Reinhard et al., 2013), U 541 concentrations (Partin et al., 2013), rare earth elements (Tang et al., 2016), Zn/Fe ratios (Liu et 542 al., 2016), and CAS (e.g., Kah et al., 2004) all indicate limited mid-Proterozoic biospheric 543 oxygenation. Independent evidence for the restriction of mid-Proterozoic marine oxygen to 544 shallow near-shore settings comes from nitrogen isotopes from multiple mid-Proterozoic 545 proximal to distal facies transects, which indicate an onshore-offshore gradient in the extent of 546 aerobic nitrogen cycling, and thus nitrate availability (Koehler et al., 2017) — an anion with a

547 similar redox sensitivity to that of $\mathrm{IO}_{3}{ }^{-}$(Emerson et al., 1979; Farrenkopf and Luther III, 2002;

548 Kennedy and Elderfield, 1987a; Kennedy and Elderfield, 1987b; Rue et al., 1997; Wong and

549 Brewer, 1977). In such a setting, it is likely that both upward and lateral mixing of $\mathrm{O}_{2}$-free waters 
550 frequently perturbed and intruded into already poorly oxygenated shallow ocean waters. Together

551 with independent evidence for mid-depth euxinia throughout the mid-Proterozoic based on iron

552 speciation analysis of shale (Fig. 6), the upward and lateral mixing of anoxic waters into weakly

553 oxygenated surface waters may also have resulted in frequent episodic incursions of hydrogen

554 sulfide into particularly shallow settings.

\section{6. Summary and implications for Proterozoic life}

556 The Proterozoic iodine record provides a comprehensive window to oxygen dynamics

557 that may have dominated ancient, marginal shallow-marine settings - the ecological hot spots that

558 likely hosted the emergence and diversification of eukaryotes, including animals (Jablonski et al.,

559 1983; Knoll, 2014). This distinction highlights the value of $\mathrm{I} /(\mathrm{Ca}+\mathrm{Mg})$ data relative to other

560 Proterozoic paleoredox records that are specific to atmospheric ( $\mathrm{Cr}$ isotopes) or deep-marine

561 anoxia (trace metals and Fe mineral speciation in shales). The overarching trends in our dataset

562 are not easily linked to diagenetic processes, and there is strong support for a primary origin of

563 iodine records across the heavily discussed Shuram excursion.

564 Previous debate regarding the potential for redox controls on the timing of early animal

565 evolution has focused on experimental and ecological analyses of animal physiology (Mills et al.,

566 2014; Sperling et al., 2013) as related to indirect estimates of atmospheric $p \mathrm{O}_{2}$ (Planavsky et al.,

567 2014). The iodine data provide a more direct perspective, suggesting the possibility of a

568 Proterozoic surface ocean that was at least intermittently hospitable to eukaryotes and that may

569 have been at, near, or above the lower limits of oxygen required for small, simple (but not large

570 and energetic) animals (Mills et al., 2014; Sperling et al., 2013). Critically, however, our data also

571 support the likelihood that the marginal shelf settings in which early protistan and, later, animal

572 fossils are found were characterized by low and variable $\mathrm{O}_{2}$ conditions (Gilleaudeau and Kah,

573 2015; Reinhard et al., 2016) most analogous to those within the oxycline directly overlying

574 modern OMZs and within anoxic basins. We argue that these conditions were particularly 
575 common through the mid-Proterozoic, with weakly oxygenated shallow waters impacted

576 frequently if not persistently by upward and lateral intrusion of abundant anoxic waters. Despite

577 maximum shallow ocean $\left[\mathrm{O}_{2}\right]$ that was likely near the proposed thresholds for simple, early

578 animals, such dynamic conditions could have challenged eukaryotic and, later, animal emergence

579 and diversification during the mid-Proterozoic for at least a billion years (Johnston et al., 2012).

$580 \quad$ Author Contributions

$581 \mathrm{DH}, \mathrm{ZL}, \mathrm{XZ}$ and $\mathrm{CD}$ analyzed $\mathrm{I} /(\mathrm{Ca}+\mathrm{Mg})$ ratios. $\mathrm{AB}, \mathrm{BG}, \mathrm{CW}, \mathrm{DH}, \mathrm{GJ}, \mathrm{LK}, \mathrm{AK}, \mathrm{SL}$,

$582 \mathrm{MO}, \mathrm{NP}$ and PS provided sample material or aided with fieldwork. DH designed the study and

583 wrote the manuscript, with major contributions from ZL and TL. MO, NP and AB also provided

584 essential input throughout. All authors discussed the results and commented on and approved

585 manuscript submission.

586 Acknowledgments

587 TL, ZL, and DH thank NSF EAR-1349252. ZL further thanks OCE-1232620. DH, ZL, and TL

588 acknowledge further funding from a NASA Early Career Collaboration Award. TL, AB, NP, DH,

589 and AK thank the NASA Astrobiology Institute. TL and NP received support from the Earth-Life

590 Transitions Program of the NSF. AB acknowledges support from NSF grant EAR-05-45484 and

591 an NSERC Discovery and Accelerator Grants. CW acknowledges support from NSFC grant

592 40972021. We also thank Peter Swart for providing the Unda and Clino drill cores, which was

593 supported by NSF funding to PS. We also thank Masha Prokopenko for contribution of carbon

594 isotope values from some GBB short cores. The authors also thank two reviewers for insightful

595 comments that greatly improved this work.

596 References

597 Bekker, A., Holland, H., 2012. Oxygen overshoot and recovery during the early Paleoproterozoic.

598 Earth and Planetary Science Letters 317, 295-304.

599

600 Blättler, C.L., Miller, N.R., Higgins, J.A., 2015. Mg and Ca isotope signatures of authigenic

601 dolomite in siliceous deep-sea sediments. Earth and Planetary Science Letters 419, 32-42.

602 Bristow, T.F., Kennedy, M.J., 2008. Carbon isotope excursions and the oxidant budget of the

603 Ediacaran atmosphere and ocean. Geology 36, 863-866. 
604 Brocks, J., Jarrett, A., Sirantoine, E., Kenig, F., Moczydłowska, M., Porter, S., Hope, J., 2016.

605 Early sponges and toxic protists: possible sources of cryostane, an age diagnostic biomarker

606 antedating Sturtian Snowball Earth. Geobiology 14, 129-149.

607 Chance, R., Baker, A.R., Carpenter, L., Jickells, T.D., 2014. The distribution of iodide at the sea

608 surface. Environmental Science: Processes \& Impacts 16, 1841-1859.

609 Cole, D.B., Reinhard, C.T., Wang, X., Gueguen, B., Halverson, G.P., Gibson, T., Hodgskiss,

610 M.S., McKenzie, N.R., Lyons, T.W., Planavsky, N.J., 2016. A shale-hosted Cr isotope record of

611 low atmospheric oxygen during the Proterozoic. Geology 44, 55-48.

612 Crowe, S.A., Døssing, L.N., Beukes, N.J., Bau, M., Kruger, S.J., Frei, R., Canfield, D.E., 2013.

613 Atmospheric oxygenation three billion years ago. Nature 501, 535-538.

614 Derry, L.A., 2010. A burial diagenesis origin for the Ediacaran Shuram-Wonoka carbon isotope

615 anomaly. Earth and Planetary Science Letters 294, 152-162.

616 Emerson, S., Cranston, R.E., Liss, P.S., 1979. Redox species in a reducing fjord: equilibrium and

617 kinetic considerations. Deep Sea Research Part A. Oceanographic Research Papers 26, 859-878.

618 Fairchild, I.J., Knoll, A.H., Swett, K., 1991. Coastal lithofacies and biofacies associated with

619 syndepositional dolomitization and silicification (Draken Formation, Upper Riphean, Svalbard).

620 Precambrian Research 53, 165-197.

621 Farrenkopf, A.M., Dollhopf, M.E., Chadhain, S.N., Luther III, G.W., Nealson, K.H., 1997.

622 Reduction of iodate in seawater during Arabian Sea shipboard incubations and in laboratory

623 cultures of the marine bacterium Shewanella putrefaciens strain MR-4. Marine Chemistry 57,

624 347-354.

625 Farrenkopf, A.M., Luther III, G.W., 2002. Iodine chemistry reflects productivity and

626 denitrification in the Arabian Sea: evidence for flux of dissolved species from sediments of

627 western India into the OMZ. Deep Sea Research Part II: Topical Studies in Oceanography 49,

$628 \quad 2303-2318$.

629 Fehn, U., 2012. Tracing crustal fluids: Applications of natural ${ }^{129} \mathrm{I}$ and ${ }^{36} \mathrm{Cl}$. Annual Review of

630 Earth and Planetary Sciences 40, 45.

631 Fike, D.A., Grotzinger, J.P., Pratt, L.M., Summons, R.E., 2006. Oxidation of the Ediacaran 632 ocean. Nature 444, 744-747.

633 Gill, B.C., Lyons, T.W., Frank, T.D., 2008. Behavior of carbonate-associated sulfate during

634 meteoric diagenesis and implications for the sulfur isotope paleoproxy. Geochimica et

635 Cosmochimica Acta 72, 4699-4711. 
636 Gilleaudeau, G., Frei, R., Kaufman, A., Kah, L., Azmy, K., Bartley, J., Chernyavskiy, P., Knoll, 637 A., 2016. Oxygenation of the mid-Proterozoic atmosphere: clues from chromium isotopes in 638 carbonates. Geochemical Perspecitves Letters 2, 178-187.

639 Gilleaudeau, G.J., Kah, L.C., 2015. Heterogeneous redox conditions and a shallow chemocline in 640 the Mesoproterozoic ocean: evidence from carbon-sulfur-iron relationships. Precambrian 641 Research 257, 94-108.

642 Glock, N., Liebetrau, V., Eisenhauer, A., 2014. I/Ca ratios in benthic foraminifera from the 643 Peruvian oxygen minimum zone: analytical methodology and evaluation as proxy for redox 644 conditions. Biogeosciences Discussions 11, 11635-11670.

645 Hardisty, D.S., Lu, Z., Planavsky, N.J., Bekker, A., Philippot, P., Zhou, X., Lyons, T.W., 2014.

646 An iodine record of Paleoproterozoic surface ocean oxygenation. Geology 42, 619-622.

647 Husson, J.M., Higgins, J.A., Maloof, A.C., Schoene, B., 2015. Ca and Mg isotope constraints on 648 the origin of Earth's deepest $\delta^{13} \mathrm{C}$ excursion. Geochimica et Cosmochimica Acta 160, 243-266.

649 Jablonski, D., Sepkoski, J.J., Bottjer, D.J., Sheehan, P.M., 1983. Onshore-offshore patterns in the 650 evolution of Phanerozoic shelf communities. Science 222, 1123-1125.

651 Johnston, D., Poulton, S., Goldberg, T., Sergeev, V., Podkovyrov, V., Vorob'eva, N., Bekker, A., 652 Knoll, A., 2012. Late Ediacaran redox stability and metazoan evolution. Earth and Planetary 653 Science Letters 335, 25-35.

654 Johnston, D.T., Poulton, S., Tosca, N., O'Brien, T., Halverson, G., Schrag, D., Macdonald, F., 655 2013. Searching for an oxygenation event in the fossiliferous Ediacaran of northwestern Canada. 656 Chemical Geology 362, 273-286.

657 Kah, L.C., 2000. Depositional $\delta^{18}$ O signatures in Proterozoic dolostones: constraints on seawater 658 chemistry and early diagenesis. SEPM Special Publication 67.

659 Kah, L.C., Lyons, T.W., Frank, T.D., 2004. Low marine sulphate and protracted oxygenation of 660 the Proterozoic biosphere. Nature 431, 834-838.

661 Kaufman, A.J., Corsetti, F.A., Varni, M.A., 2007. The effect of rising atmospheric oxygen on 662 carbon and sulfur isotope anomalies in the Neoproterozoic Johnnie Formation, Death Valley, 663 USA. Chemical Geology 237, 47-63.

664 Kennedy, H., Elderfield, H., 1987a. Iodine diagenesis in non-pelagic deep-sea sediments.

665 Geochimica et Cosmochimica Acta 51, 2505-2514.

666 Kennedy, H.A., Elderfield, H., 1987b. Iodine diagenesis in pelagic deep-sea sediments. 667 Geochimica et Cosmochimica Acta 51, 2489-2504. 
670 Knoll, A.H., 2014. Paleobiological perspectives on early eukaryotic evolution. Cold Spring

671 Harbor perspectives in biology 6, a016121.

672 Koehler, M.C., Stüeken, E.E., Kipp, M.A., Buick, R., Knoll, A.H., 2017. Spatial and temporal

673 trends in Precambrian nitrogen cycling: a Mesoproterozoic offshore nitrate minimum.

674 Geochimica et Cosmochimica Acta 198, 315-337.

675 Lee, C., Love, G.D., Fischer, W.W., Grotzinger, J.P., Halverson, G.P., 2015. Marine organic

676 matter cycling during the Ediacaran Shuram excursion. Geology 43, 1103-1106.

677 Liu, X., Kah, L., Knoll, A., Cui, H., Kaufman, A., Shahar, A., Hazen, R., 2016. Tracing Earth's

$678 \mathrm{O}_{2}$ evolution using $\mathrm{Zn} / \mathrm{Fe}$ ratios in marine carbonates. Geochemical Perspectives Letters 2, 24-34.

679 Loope, G.R., Kump, L.R., Arthur, M.A., 2013. Shallow water redox conditions from the 680 Permian-Triassic boundary microbialite: The rare earth element and iodine geochemistry of 681 carbonates from Turkey and South China. Chemical Geology 351, 195-208.

682 Loyd, S.J., Berelson, W.M., Lyons, T.W., Hammond, D.E., Corsetti, F.A., 2012. Constraining 683 pathways of microbial mediation for carbonate concretions of the Miocene Monterey Formation 684 using carbonate-associated sulfate. Geochimica et Cosmochimica Acta 78, 77-98.

685 Loyd, S.J., Marenco, P.J., Hagadorn, J.W., Lyons, T.W., Kaufman, A.J., Sour-Tovar, F., Corsetti, 686 F.A., 2013. Local $\delta^{34}$ S variability in 580 Ma carbonates of northwestern Mexico and the 687 Neoproterozoic marine sulfate reservoir. Precambrian Research 224, 551-569.

688 Lu, Z., Hoogakker, B.A., Hillenbrand, C.-D., Zhou, X., Thomas, E., Gutchess, K.M., Lu, W., 689 Jones, L., Rickaby, R.E., 2016. Oxygen depletion recorded in upper waters of the glacial 690 Southern Ocean. Nature Communications 7.

691 Lu, Z., Jenkyns, H.C., Rickaby, R.E., 2010. Iodine to calcium ratios in marine carbonate as a 692 paleo-redox proxy during oceanic anoxic events. Geology 38, 1107-1110.

693 Luther III, G.W., Wu, J., Cullen, J.B., 1995. Redox Chemistry of Iodine in Seawater: Frontier 694 Molecular Orbital Theory Considerations. Aquatic chemistry: interfacial and interspecies 695 processes $244,135$.

696 Lyons, T.W., Reinhard, C.T., Planavsky, N.J., 2014. The rise of oxygen in Earth's early ocean 697 and atmosphere. Nature 506, 307-315.

698 Manfrino, C.M., Ginsburg, R.N., 2001. Pliocene to Pleistocene deposition history of the upper 699 platform margin. SEPM Special Publication 70, 17-39. 

implications for the use of petrography to identify diagenetic environments. Geology 23, 755758.

708 Mitchell, R., Sheldon, N., 2009. Weathering and paleosol formation in the 1.1 Ga Keweenawan

713 Muramatsu, Y., Hans Wedepohl, K., 1998. The distribution of iodine in the earth's crust.

714 Chemical Geology 147, 201-216.

715 Osburn, M.R., Owens, J., Bergmann, K.D., Lyons, T.W., Grotzinger, J.P., 2015. Dynamic

716 changes in sulfate sulfur isotopes preceding the Ediacaran Shuram Excursion. Geochimica et

717 Cosmochimica Acta 170, 204-224.

718 Owens, J.D., Lyons, T.W., Hardisty, D.S., Lowery, C.M., Lu, Z., Lee, B., \& Jenkyns, H.C., 2017, 719 Patterns of local and global redox variability during the Cenomanian-Turonian Boundary Event $64,168-185$

Partin, C., Bekker, A., Planavsky, N., Scott, C., Gill, B., Li, C., Podkovyrov, V., Maslov, A., Konhauser, K., Lalonde, S., 2013. Large-scale fluctuations in Precambrian atmospheric and oceanic oxygen levels from the record of U in shales. Earth and Planetary Science Letters 369, 284-293. 

A., Konhauser, K.O., Lyons, T.W., 2013. Proterozoic ocean redox and biogeochemical stasis. Proceedings of the National Academy of Sciences 110, 5357-5362.

738 Romaniello, S.J., Herrmann, A.D., Anbar, A.D., 2013. Uranium concentrations and ${ }^{238} \mathrm{U} /{ }^{235} \mathrm{U}$ 739 isotope ratios in modern carbonates from the Bahamas: Assessing a novel paleoredox proxy.

740 Chemical Geology 362, 305-316.

741 Rothman, D.H., Hayes, J.M., \& Summons, R. E., 2003), Dynamics of the Neoproterozoic carbon

742 cycle. Proceedings of the National Academy of Sciences 100, 8124-8129.

743 Rue, E.L., Smith, G.J., Cutter, G.A., Bruland, K.W., 1997. The response of trace element redox

744 couples to suboxic conditions in the water column. Deep Sea Research Part I: Oceanographic

745 Research Papers 44, 113-134.

746

747

748

749

750

751

752

753

754

755

756

757

758

759

760

761

762

763

764

765

766

767
Schrag, D.P., Higgins, J.A., Macdonald, F.A., Johnston, D.T., 2013. Authigenic carbonate and the history of the global carbon cycle. Science 339, 540-543.

Sperling, E.A., Halverson, G.P., Knoll, A.H., Macdonald, F.A., Johnston, D.T., 2013. A basin redox transect at the dawn of animal life. Earth and Planetary Science Letters 371, 143-155.

Sperling, E.A., Wolock, C.J., Morgan, A.S., Gill, B.C., Kunzmann, M., Halverson, G.P., Macdonald, F.A., Knoll, A.H., Johnston, D.T., 2015. Statistical analysis of iron geochemical data suggests limited late Proterozoic oxygenation. Nature 523, 451-454.

Swart, P.K., Kennedy, M.J., 2012. Does the global stratigraphic reproducibility of $\delta^{13} \mathrm{C}$ in Neoproterozoic carbonates require a marine origin? A Pliocene-Pleistocene comparison. Geology 40, 87-90.

Swart, P.K., Melim, L.A., 2000. The origin of dolomites in Tertiary sediments from the margin of Great Bahama Bank. Journal of Sedimentary Research 70, 738-748.

Tang, D., Shi, X., Wang, X., Jiang, G., 2016. Extremely low oxygen concentration in midProterozoic shallow seawaters. Precambrian Research 276, 145-157.

Tucker, M.E., 1982. Precambrian dolomites: petrographic and isotopic evidence that they differ from Phanerozoic dolomites. Geology 10, 7-12.

Vahrenkamp, V., Swart, P., 1994. Late Cenozoic dolomites of the Bahamas: metastable analogues for the genesis of ancient platform dolomites. Dolomites: A Volume in Honour of Dolomieu 21, 133-153.

van Smeerdijk Hood, A., Wallace, M.W., Drysdale, R.N., 2011. Neoproterozoic aragonitedolomite seas? Widespread marine dolomite precipitation in Cryogenian reef complexes. Geology 39, 871-874. 
768 Wong, G.T., Brewer, P.G., 1977. The marine chemistry of iodine in anoxic basins. Geochimica et

769 Cosmochimica Acta 41, 151-159.

770 Zhang, S., Henehan, M.J., Hull, P.M., Reid, R.P., Hardisty, D.S., Hood, A., Planavsky, N.J.,

771 2017, Environmental and biological controls on boron isotope ratios in shallow marine

772 carbonates. Earth and Planetary Science Letters, 458, 380-393.

773 Zhao, M.-Y., Zheng, Y.-F., Zhao, Y.-Y., 2016. Seeking a geochemical identifier for authigenic 774 carbonate. Nature Communications 7.

775 Zhou, X., Jenkyns, H.C., Owens, J.D., Junium, C.K., Zheng, X.Y., Sageman, B.B., Hardisty, 776 D.S., Lyons, T.W., Ridgwell, A., Lu, Z., 2015. Upper ocean oxygenation dynamics from I/Ca 777 ratios during the Cenomanian-Turonian OAE 2. Paleoceanography 30.5, 510-526.

778 Zhou, X., Thomas, E., Rickaby, R.E., Winguth, A.M., Lu, Z., 2014. I/Ca evidence for upper 779 ocean deoxygenation during the PETM. Paleoceanography 29, 964-975. 
781 Table 1. Approximate ages and number of samples for Proterozoic geologic units measured for

$782 \mathrm{I} /(\mathrm{Ca}+\mathrm{Mg})$ ratios in this study. References to ages and lithological descriptions can be found in 783 the supplementary materials.

784 Table 2. Approximate ages and number of samples for Neogene-Quaternary geologic units 785 measured for $\mathrm{I} /(\mathrm{Ca}+\mathrm{Mg})$ ratios in this study. Also shown are the diagenetic conditions affecting 786 mineralogy at each study site. The relevant previous publications providing lithological, 787 geochemical, and diagenetic constraints are provided in the Supplementary Materials and in some 788 cases in the main text. Supplementary Figure 1 contains a map of the sampling localities.

789 Table 3. Coordinates, water depth, key depositional features, and mineralogy for cores from near 790 Little Darby and Lee Stocking Islands, Bahamas. Mineralogy is shown in wt. \% of high-Mg 791 calcite (HMC). None of the cores contained dolomite and only minor calcite was found in the 792 cores, with HMC + aragonite > 93.52 wt. \% in all cases, meaning that the sediments mostly 793 consist of aragonite. The detailed mineralogy, $\delta^{13} \mathrm{C}_{\text {carb }}, \delta^{18} \mathrm{O}_{\text {carb }}$, and $\mathrm{I} /(\mathrm{Ca}+\mathrm{Mg})$ for each sample 794 can be found in Supplementary Table 1. Also shown is the $\mathrm{I} /(\mathrm{Ca}+\mathrm{Mg})$ value for uppermost 795 sediment sample and the range for all depths from each short core. Supplementary Figure 1 796 contains a map of the sampling localities and Supplementary Figure 2 shows vertical profiles of $797 \mathrm{I} /(\mathrm{Ca}+\mathrm{Mg}), \delta^{13} \mathrm{C}_{\mathrm{carb}}$, and wt. \% aragonite for each of the cores. 
799 Fig. 1. Water column dissolved $\left[\mathrm{IO}_{3}{ }^{-}\right]$and $\left[\mathrm{O}_{2}\right]$ from a vertical transect through the Peruvian

800 OMZ (Rue et al., 1997). The vertical dashed line highlights the range of $\left[\mathrm{IO}_{3}{ }^{-}\right](<250 \mathrm{nM})$ that is

801 nearly exclusively observed in settings within or below the oxycline of marine anoxic basins and

802 OMZs (Lu et al., 2016). The shaded box refers to the portion of the profile where corresponding

$803 \mathrm{I} /(\mathrm{Ca}+\mathrm{Mg})$ ratios are anticipated to be $<2.6 \mu \mathrm{mol} / \mathrm{mol}$ (Glock et al., 2014; Lu et al., 2016), which

804 is further discussed in the main text.

805 Fig. 2. (a) $\mathrm{I} /(\mathrm{Ca}+\mathrm{Mg})$ and (b) $\delta^{13} \mathrm{C}_{\text {carb }}$ for transects through three aragonite-dominated to calcite-

806 dominated portions of (c) Montastrea annularis coral heads of the Pleistocene Key Largo

807 Limestone of South Florida. The samples and transects are exactly the same as those used in Gill

808 et al. (2008). The horizontal dashed line at $2.6 \mu \mathrm{mol} / \mathrm{mol}$ (part a) represents the $\mathrm{I} /(\mathrm{Ca}+\mathrm{Mg}$ ) ratio

809 range found in calcitic forams from low oxygen water column settings (Glock et al., 2014; Lu et

810 al., 2016). A picture of the KL-1 coral head and drilled transect is shown in part c as an example,

811 with the circles representing discrete sampling locations. The transect is drilled at centimeter

812 intervals across a mineralogical transition from aragonite to calcite driven by subaerial exposure

813 and diagenesis in meteoric pore fluids. The aragonite can be discerned by the lighter color and the

814 calcite by the darker color, with the reaction void occurring between KL1-3 and KL1-4. Scale bar

815 in bottom right hand corner is $1 \mathrm{~cm}$.

816 Fig. 3. The (a) facies and lithology (horizontal and slanted lines represent ramp paleo geometry;

817 Swart and Melim, 2000), (b) carbonate mineralogy (aragonite-dark grey; HMC-red, LMC-white;

818 dolomite-blue), (c) $\delta^{13} \mathrm{C}_{\text {carb}}$, and (d) $\mathrm{I} /(\mathrm{Ca}+\mathrm{Mg})$ ratios for the Clino core of the Great Bahama

819 Bank. Lithological descriptions come from Kenter and others (2001) and Manfrino and others

820 (2001). The vertical dashed line at $2.6 \mu \mathrm{mol} / \mathrm{mol}$ represents the $\mathrm{I} /(\mathrm{Ca}+\mathrm{Mg})$ ratio range found in

821 calcitic forams from low oxygen water column settings (Glock et al., 2014; Lu et al., 2016).

822 Fig. 4. The composition of (a) primary aragonite and high-Mg calcite and (b) diagenetic 823 dolomite relative to $\mathrm{I} /(\mathrm{Ca}+\mathrm{Mg})$ ratios for the diagenetic sample set described in the main text and

824 labeled in the legend. The horizontal dashed line is at an $\mathrm{I} /(\mathrm{Ca}+\mathrm{Mg})$ of $2.6 \mu \mathrm{mol} / \mathrm{mol}$, the 825 threshold, which, as discussed in the text, is characteristic of reducing marine setting (Glock et 826 al., 2014; Lu et al., 2016).

827 Fig. 5. Comparison of $\mathrm{I} /(\mathrm{Ca}+\mathrm{Mg})$ to $\mathrm{Mg} / \mathrm{Ca}$ for the Neogene dolomite-bearing sample sets from 828 this study relative to the Proterozoic sample set from this and previous Proterozoic studies 829 (Hardisty et al., 2014). 
830 Fig. 6. Compilation of proxy data distinguishing the redox state of the atmosphere (upper panel),

831 surface ocean (middle panel), and deeper ocean (lower panel). Events discussed in the text are

832 labeled, including the period when the major eukaryotic diversification took place (vertical gray

833 bar; from Knoll, 2014). Upper panel: The secular trend in atmospheric oxygen as discussed in

834 recent compilations (Lyons et al., 2014; Planavsky et al., 2014). Dashed lines in the upper panel

835 represent uncertainty due to a lack of quantitative constraints. Middle panel: $\delta^{13} \mathrm{C}_{\text {carb }}$ (upper

836 thick black line) and $\mathrm{I} /(\mathrm{Ca}+\mathrm{Mg})$ (Glock et al., 2014; Hardisty et al., 2014; Loope et al., 2013; Lu

837 et al., 2016; Lu et al., 2010; Zhou et al., 2015; Zhou et al., 2014). I/(Ca+Mg) ratios reflect surface

838 ocean redox conditions. Blue symbols on the right side represent samples from modern to recent

839 settings with independent evidence for a well-oxygenated water column and lacking indicators of

840 diagenetic overprinting. This includes foraminifera (Lu et al., 2016), aragonitic coral heads of the

841 Key Largo Limestone from this study, and aragonite- to HMC-dominated bulk carbonate from the

842 modern Great Bahama Bank of this study. The yellow symbols correspond to modern

843 foraminifera from within the oxycline of reducing settings (Glock et al., 2014; Lu et al., 2016).

844 The square symbols indicate data representing $\mathrm{I} / \mathrm{Ca}$ from calcitic foraminifera, equivalent to

$845 \mathrm{I} /(\mathrm{Ca}+\mathrm{Mg})$ in the case of calcite. Bottom panel: Generalized deep-ocean redox, as inferred from

846 previous work utilizing iron mineral speciation (Sperling et al., 2015). Red and purple boxes

847 represent ferruginous and euxinic deep-marine waters, respectively.

848 Fig. 7. The $\delta^{13} \mathrm{C}_{\text {carb}}, \mathrm{I} /(\mathrm{Ca}+\mathrm{Mg})$ ratios, and stratigraphic profiles for Ediacaran successions

849 capturing the Shuram anomaly: (A) Khufai Formation, Oman $\left(\delta^{13} \mathrm{C}_{\text {carb }}\right.$ and stratigraphy from

850 Osburn et al., 2015), (B) the Johnnie Formation, Death Valley, USA, (C) Clemente Formation,

851 Northern Mexico $\left(\delta^{13} \mathrm{C}_{\text {carb }}\right.$ and stratigraphy from Loyd et al., 2013), and (D) Doushantuo

852 Formation, Siduping of South China. $1 \sigma$ for $\mathrm{I} /(\mathrm{Ca}+\mathrm{Mg}$ ) is equal to $0.2 \mu \mathrm{mol} / \mathrm{mol}$ (see Methods),

853 twice the width of the data points. The Ediacaran paleogeographic reconstruction is adapted from

854 Pisarevsky and others (2008). 


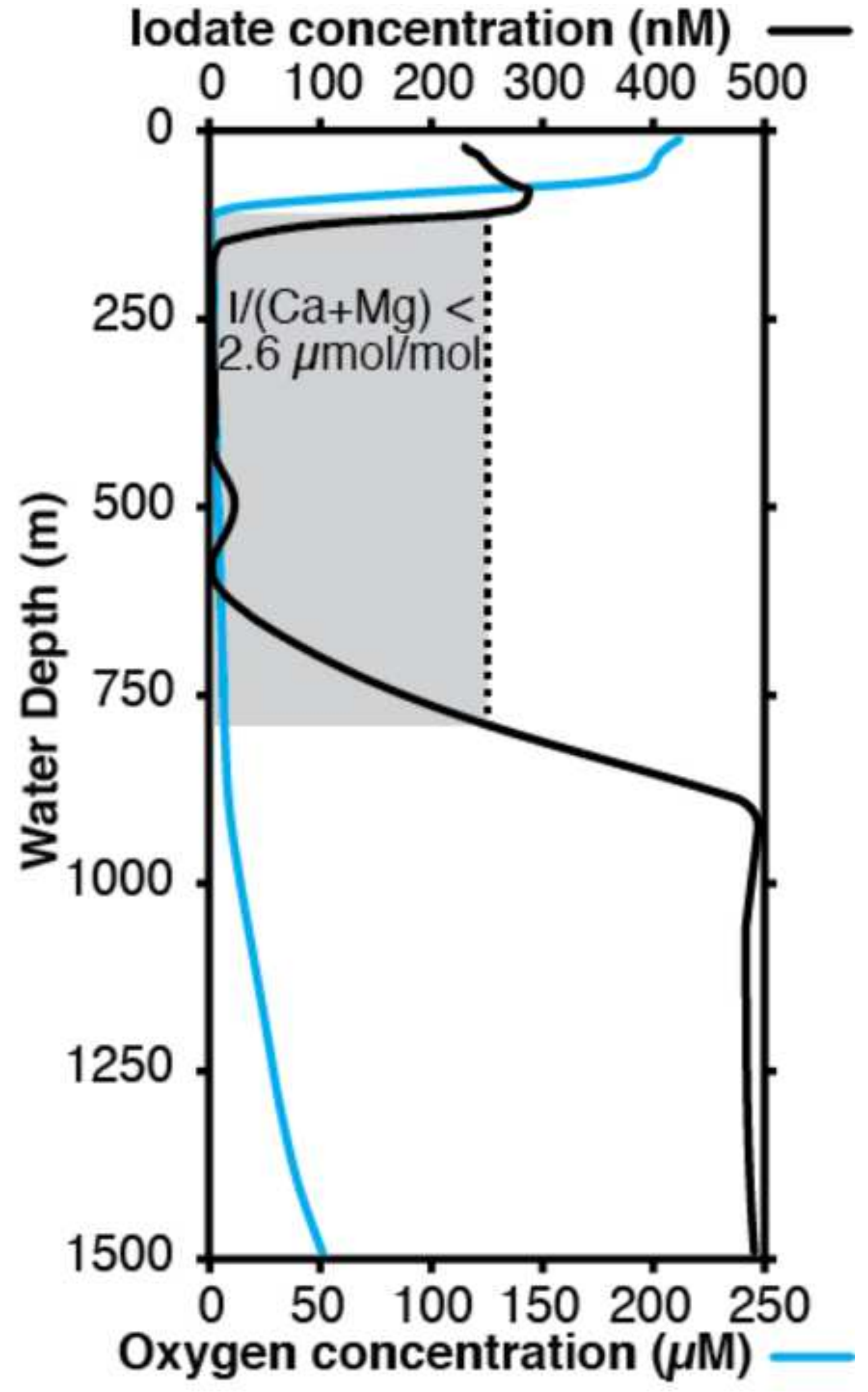

lodate concentration (nM)

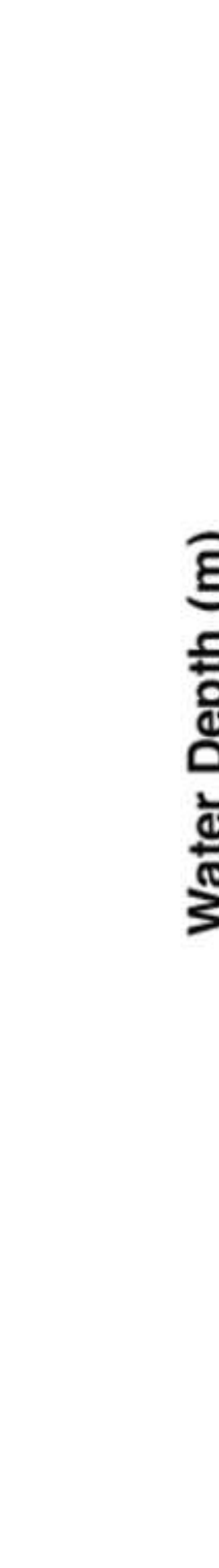

$-$

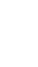


Key Largo Limestone, South Florida, Pleistocene
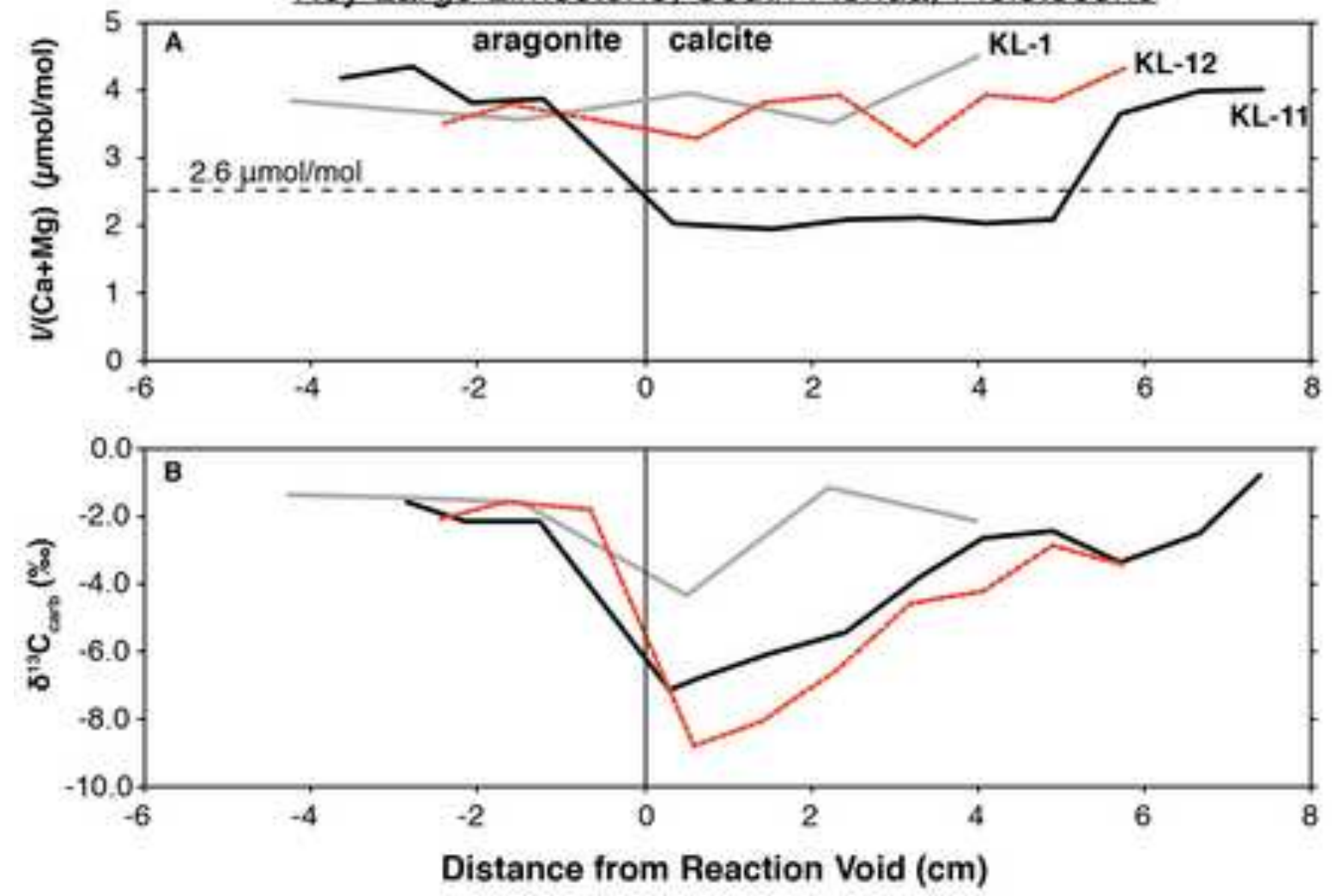

\section{Montastrea annularis}

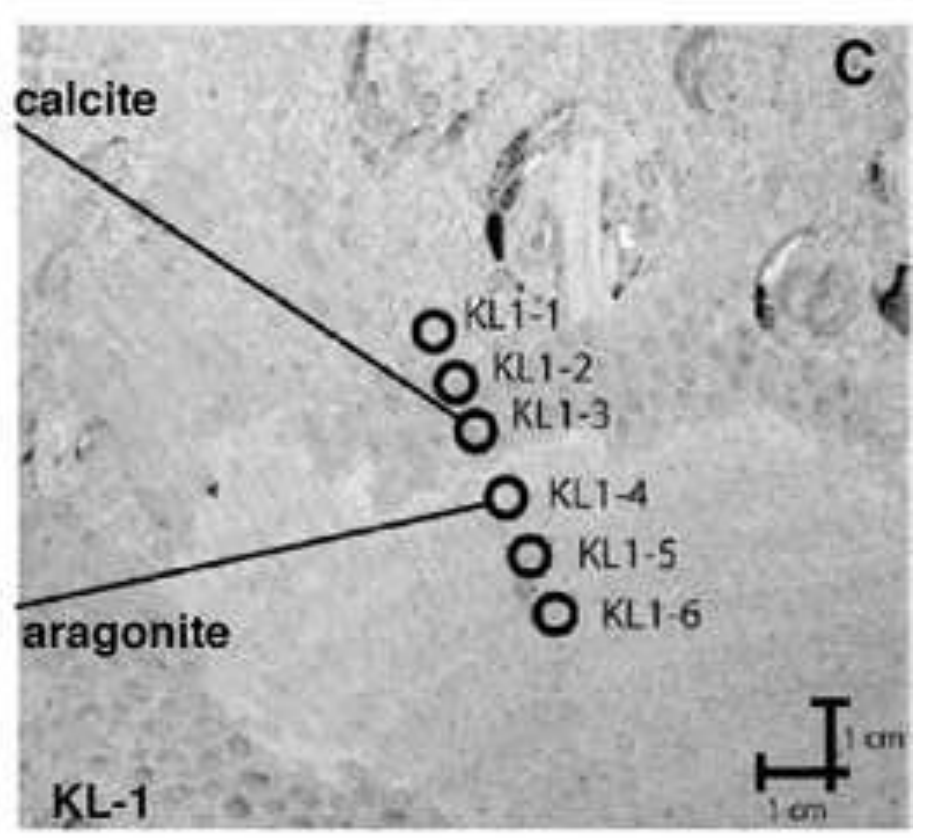




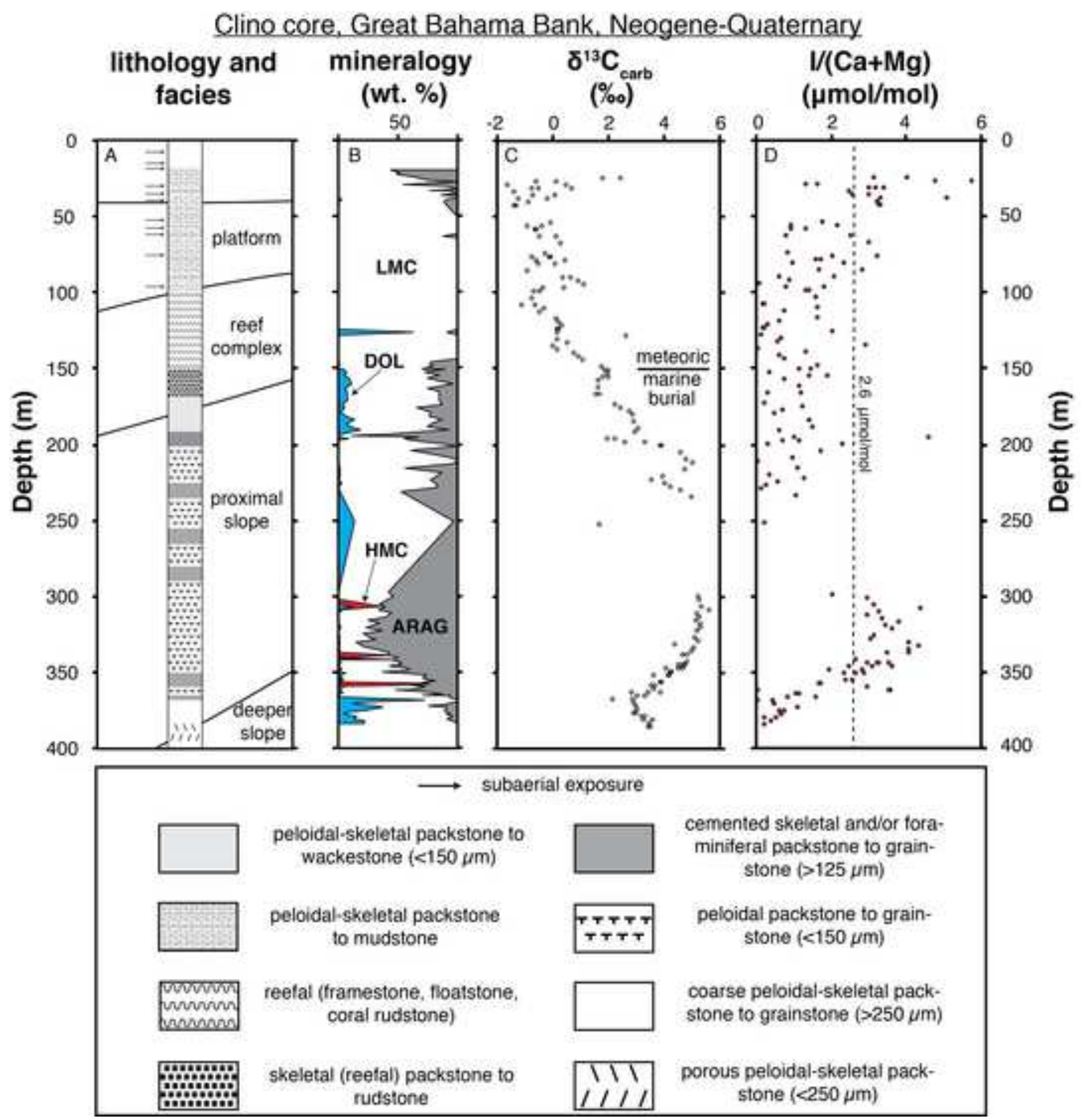




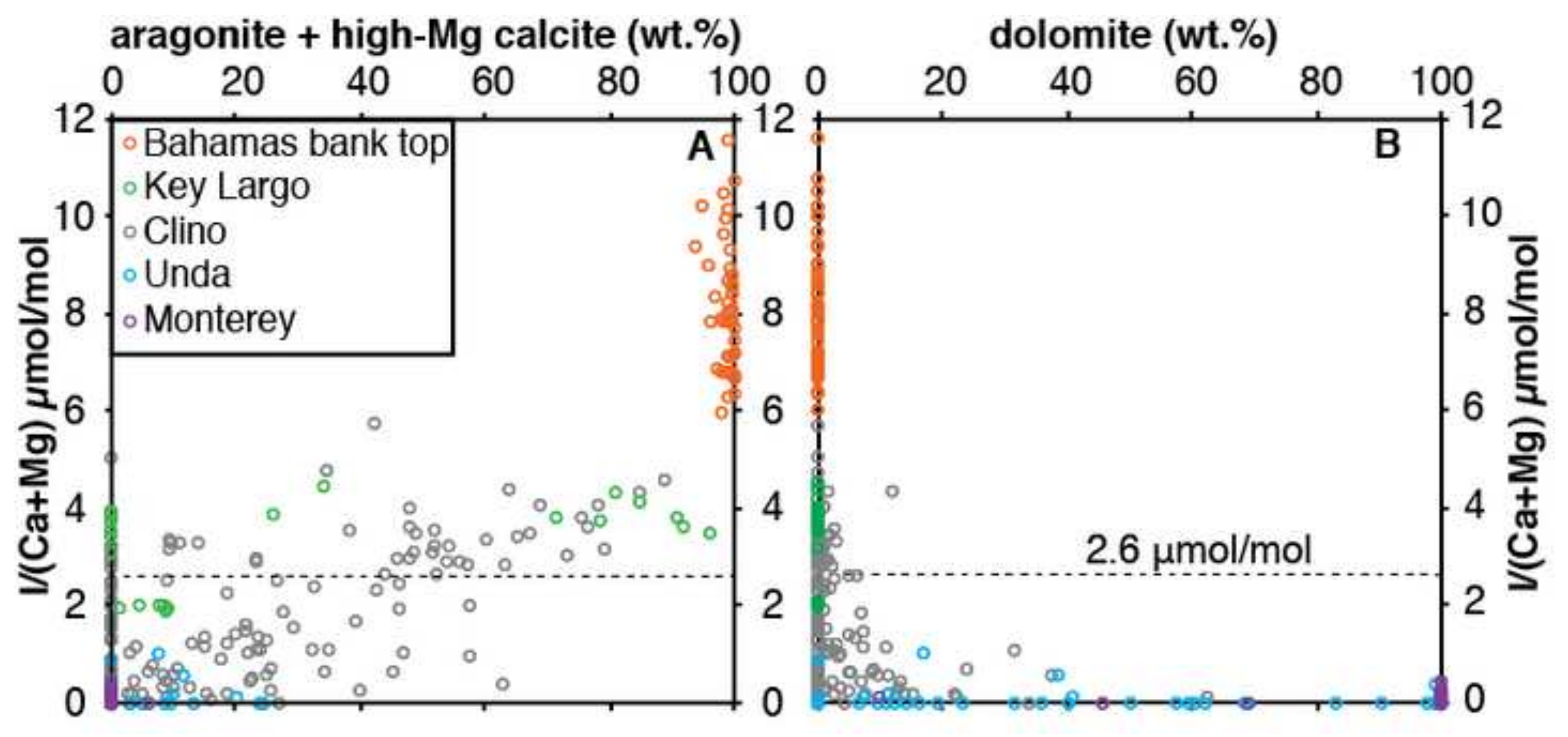




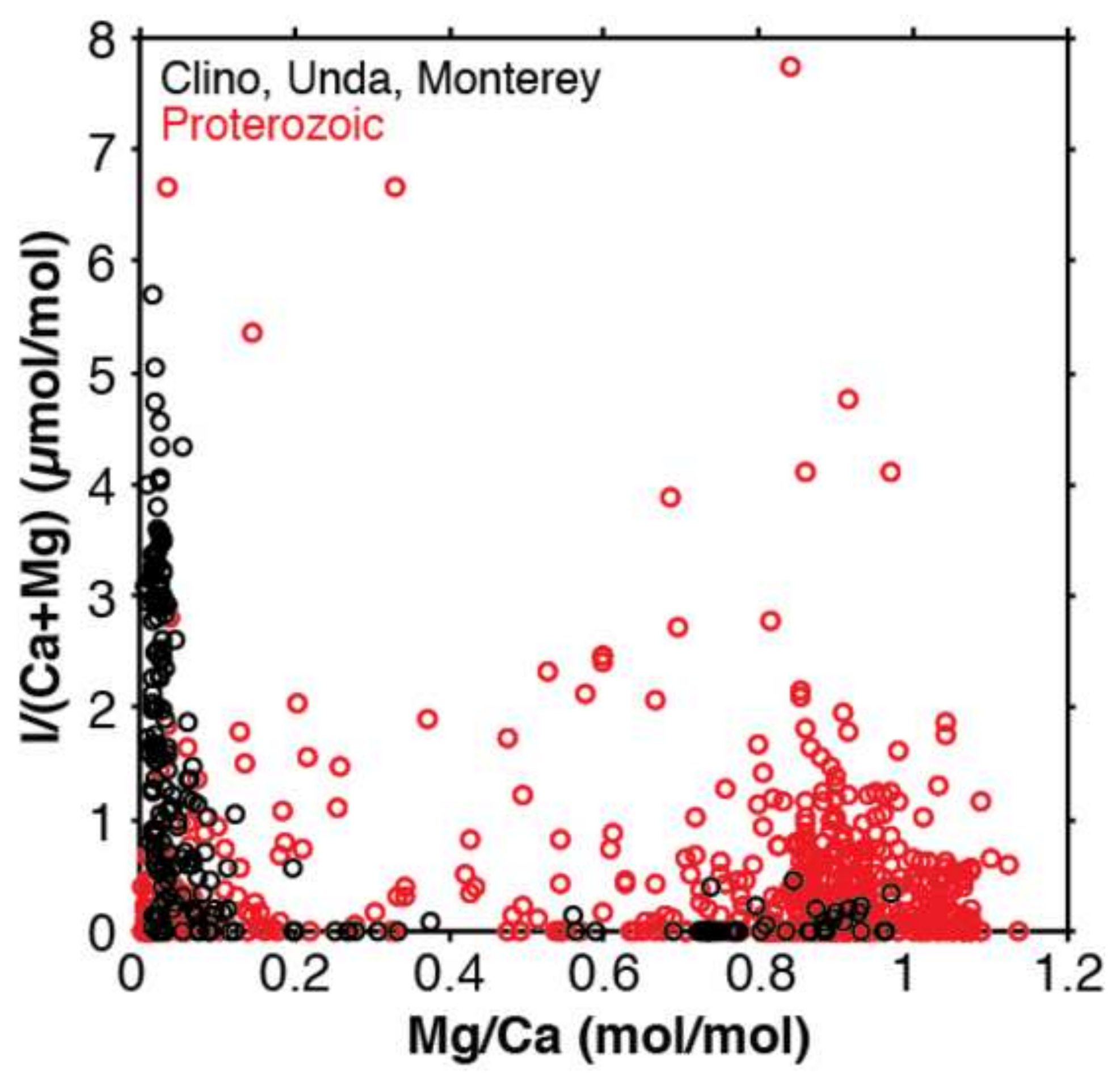




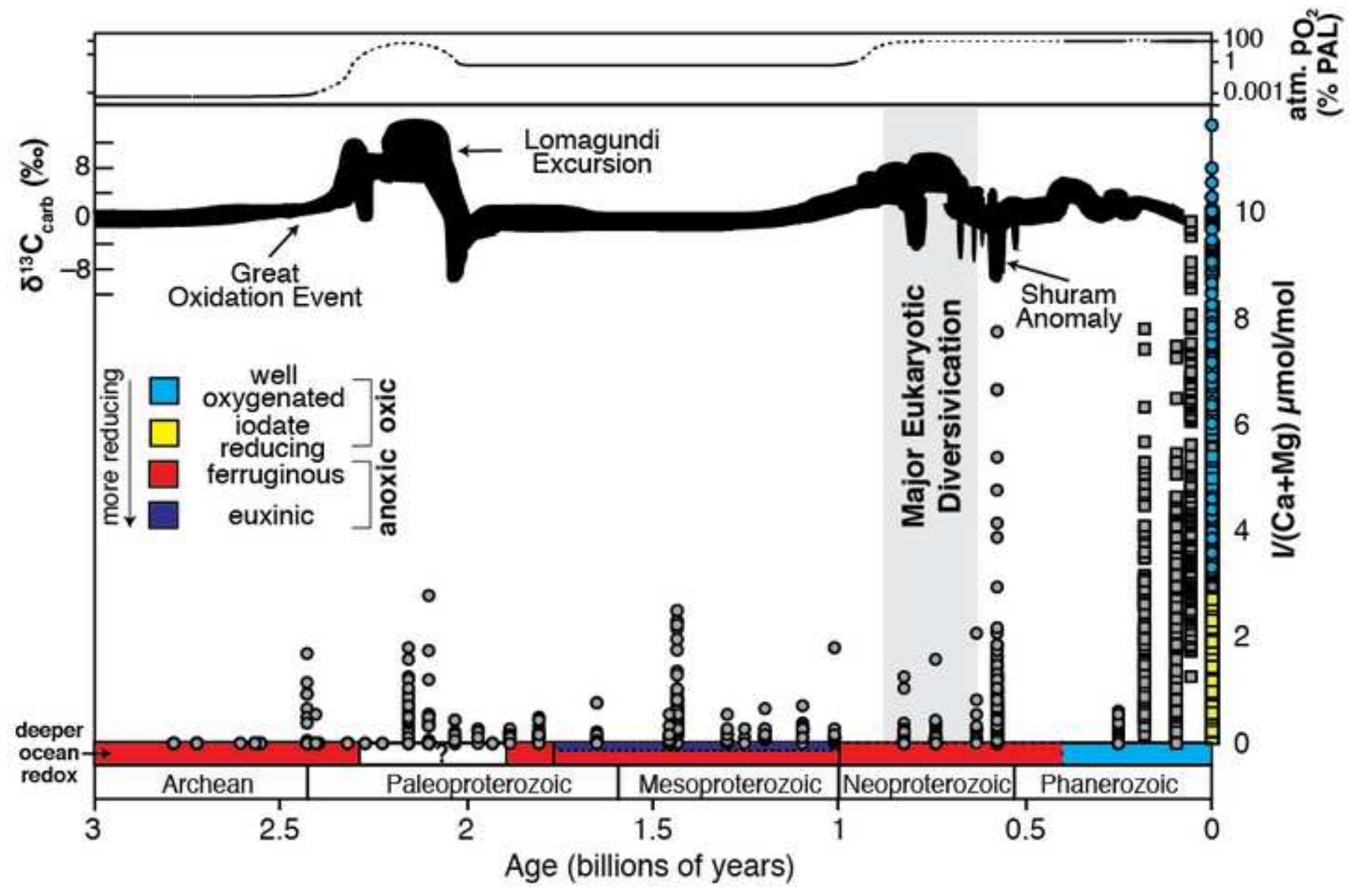




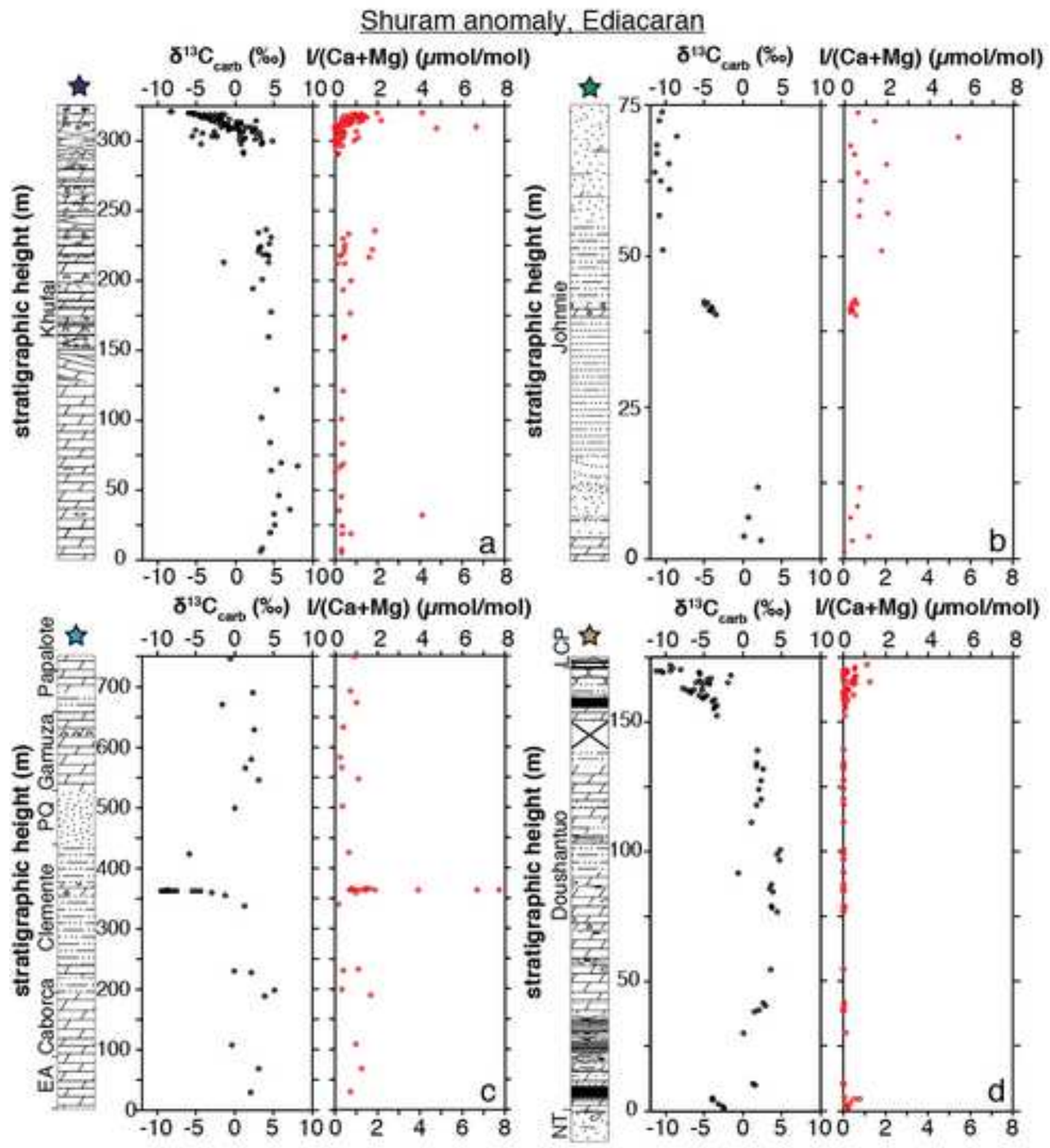

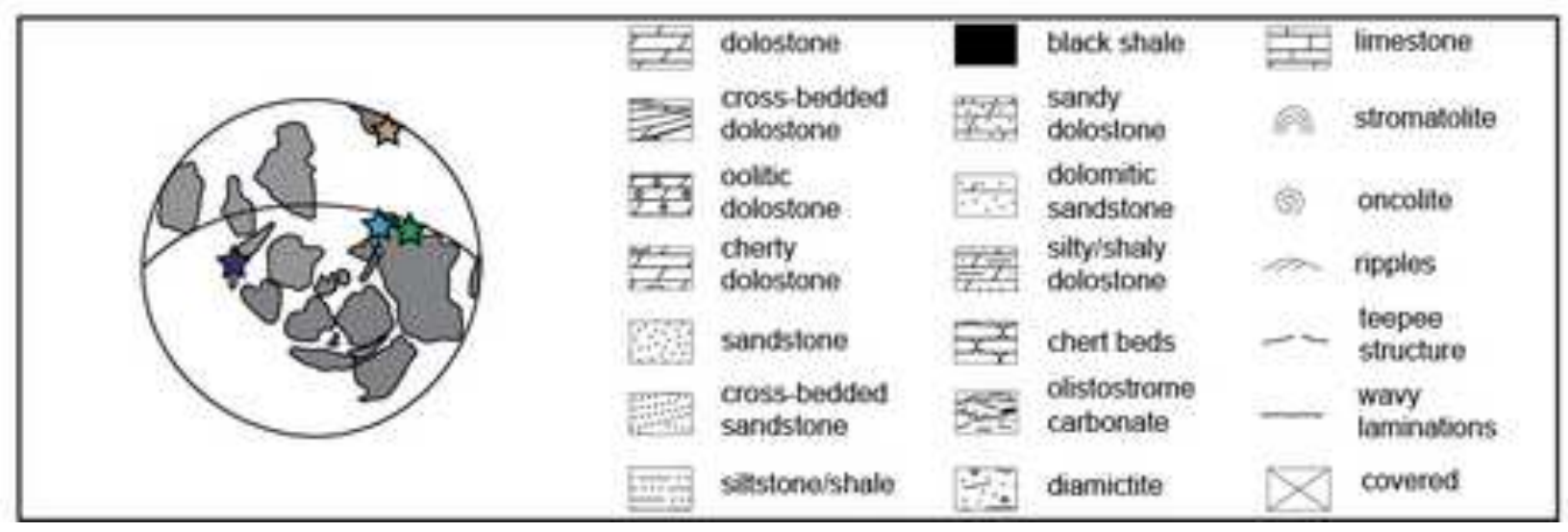


Table 1.

\begin{tabular}{|c|c|c|}
\hline Geologic Unit & $\begin{array}{c}\text { Approximate Age } \\
\text { (billions of years) }\end{array}$ & n \\
\hline Wooly Dolomite, Australia & 2.03 & 11 \\
\hline Snare Group, Canada & 1.97 & 4 \\
\hline Taltheilei Formation, Canada & 1.88 & 14 \\
\hline Duck Creek Formation, Australia & 1.80 & 22 \\
\hline Paradise Creek Formation, Australia & 1.65 & 10 \\
\hline Helena Formation, USA & 1.45 & 9 \\
\hline Tieling Formation, China & 1.44 & 45 \\
\hline Kaltasy Formation, Russia & 1.43 & 12 \\
\hline Dismal Lakes Group, Canada & 1.30 & 16 \\
\hline Mescal Formation, USA & 1.26 & 4 \\
\hline Angmaat Formation, Canada & 1.15 & 17 \\
\hline Atar and El Mreiti groups, Mauritania & 1.10 & 17 \\
\hline Sukhaya Tunguska Formation, Russia & 1.04 & 7 \\
\hline Shaler Group, Canada & 0.85 & 17 \\
\hline Akademikerbeen Group, Svalbard; & 0.83 & 36 \\
\hline Limestone-Dolomite Series, Greenland & 0.75 & 20 \\
\hline Beck Springs Dolomite, USA & 0.58 & 122 \\
\hline Khufai Formation, Sultanate of Oman & 0.58 & 30 \\
\hline Johnnie Formation, USA & 0.58 & 31 \\
\hline Clemente Formation, Mexico & $0.64-0.58$ & 74 \\
\hline Doushantuo Formation, China (Siduping) & &
\end{tabular}


Table 2.

\begin{tabular}{|c|c|c|c|}
\hline Age & Location & Diagenetic Setting & $\mathbf{n}$ \\
\hline modern & $\begin{array}{c}\text { Little Darby and Lee } \\
\text { Stocking Islands, } \\
\text { Bahamas }\end{array}$ & initial deposition & 57 \\
\hline Pleistocene & $\begin{array}{c}\text { Key Largo Limestone, } \\
\text { South Florida }\end{array}$ & $\begin{array}{c}\text { initial deposition, } \\
\text { meteoric }\end{array}$ & 30 \\
\hline $\begin{array}{c}\text { Neogene- } \\
\text { Quaternary }\end{array}$ & Clino, Bahamas & $\begin{array}{c}\text { meteoric, marine } \\
\text { burial, dolomitization }\end{array}$ & 151 \\
\hline $\begin{array}{c}\text { Neogene- } \\
\text { Quaternary }\end{array}$ & Unda, Bahamas & dolomitization & 49 \\
\hline Miocene & $\begin{array}{c}\text { Monterey Formation, } \\
\text { Central California }\end{array}$ & $\begin{array}{c}\text { authigenic dolomite } \\
\text { concretions }\end{array}$ & 24 \\
\hline
\end{tabular}


Table 3.

\begin{tabular}{|c|c|c|c|c|c|c|}
\hline \multirow[t]{2}{*}{ Core } & \multirow[t]{2}{*}{ Coordinates } & \multirow{2}{*}{$\begin{array}{c}\text { Water } \\
\text { Depth (m) }\end{array}$} & \multirow[t]{2}{*}{ Key Features } & \multirow{2}{*}{$\begin{array}{l}\text { HMC } \\
(\text { wt. \%) }\end{array}$} & \multicolumn{2}{|c|}{$\begin{array}{l}\mathrm{I} /(\mathrm{Ca}+\mathrm{Mg}) \\
(\mu \mathrm{mol} / \mathrm{mol})\end{array}$} \\
\hline & & & & & Surface & Range \\
\hline $\mathrm{C} 1$ & $\begin{array}{l}23^{\circ} 51^{\prime 2} 24.59^{\prime \prime} \mathrm{N} \\
76^{\circ} 13^{\prime} 30.85^{\prime \prime} \mathrm{W}\end{array}$ & $<1$ & intertidal & $6.6-23.0$ & 10.2 & $\begin{array}{l}8.1- \\
10.2 \\
\end{array}$ \\
\hline $\mathrm{C} 3$ & $\begin{array}{l}23^{\circ} 51^{\prime} 24.68^{\prime \prime} \mathrm{N} \\
76^{\circ} 13^{\prime} 33.25^{\prime \prime} \mathrm{W} \\
\end{array}$ & $<5$ & $\begin{array}{c}\text { subtidal/Thalassia testudinum } \\
\text { bed }\end{array}$ & $\begin{array}{l}15.2- \\
25.6 \\
\end{array}$ & 7.6 & $6.7-7.6$ \\
\hline $\begin{array}{l}\text { C4, } \\
\text { C6 }\end{array}$ & $\begin{array}{l}23^{\circ} 46^{\prime} 11.21 " \mathrm{~N} \\
76^{\circ} 6^{\prime} 48.92^{\prime \prime} \mathrm{W}\end{array}$ & $<10$ & $\begin{array}{c}\text { subtidal/former ooid } \\
\text { shoal/peloid rich/Thalassia } \\
\text { testudinum bed }\end{array}$ & $\begin{array}{c}13.7- \\
31.3 ; \\
8.1-26.5 \\
\end{array}$ & $\begin{array}{c}10.0 \\
9.4\end{array}$ & $\begin{array}{c}8.4- \\
10.8 \\
7.7-9.4\end{array}$ \\
\hline C5 & $\begin{array}{c}23^{\circ} 45^{\prime} 57.18^{\prime \prime N} \\
76^{\circ} 88^{\prime} 3.00^{\prime \prime} \mathrm{W}\end{array}$ & $<10$ & $\begin{array}{l}\text { subtidal/active ooid shoal/ooid } \\
\text { aggregates or grapestones }\end{array}$ & $4.7-9.3$ & 11.6 & $\begin{array}{l}6.0- \\
11.6 \\
\end{array}$ \\
\hline $\mathrm{C} 7$ & $\begin{array}{l}23^{\circ} 46^{\prime} 10.78^{\prime \prime} \mathrm{N} \\
76^{\circ} 6^{\prime} 51.48^{\prime \prime} \mathrm{W}\end{array}$ & $<10$ & $\begin{array}{l}\text { subtidal/active ooid shoal/ooid } \\
\text { aggregates or grapestones }\end{array}$ & $4.3-10.3$ & 7.2 & $6.7-7.5$ \\
\hline $\mathrm{C} 8$ & $\begin{array}{l}23^{\circ} 51^{\prime 2} 21.55^{\prime \prime N} \\
76^{\circ} 13^{\prime} 33.52^{\prime \prime} \mathrm{W}\end{array}$ & $<2$ & $\begin{array}{c}\text { subtidal/active ooid shoal/ooid } \\
\text { aggregates or grapestones }\end{array}$ & $8.8-24.1$ & 8.2 & $6.3-8.2$ \\
\hline
\end{tabular}

